\title{
B Cell Orchestration of Anti-tumor Immune Responses: A Matter of Cell Localization and Communication
}

\author{
Gabriela Sarti Kinker ${ }^{1 t}$, Glauco Akelinghton Freire Vitiello ${ }^{1,2 t}$, \\ Wallax Augusto Silva Ferreira' ${ }^{1,3 t}$, Alexandre Silva Chaves ${ }^{1+}$, \\ Vladmir Cláudio Cordeiro de Lima ${ }^{4,5}$ and Tiago da Silva Medina ${ }^{1,6 *}$ \\ 1 Translational Immuno-oncology Group, International Research Center, A.C. Camargo Cancer Center, São Paulo, Brazil, \\ ${ }^{2}$ Department of Pathological Sciences, Londrina State University, Londrina, Brazil, ${ }^{3}$ Laboratory of Tissue Culture and \\ Cytogenetics, Environment Section (SAMAM), Evandro Chagas Institute, Ananindeua, Brazil, ${ }^{4}$ Instituto do Câncer do Estado \\ de São Paulo (ICESP), São Paulo, Brazil, ${ }^{5}$ Oncologia D'Or São Paulo, Rede D'or, São Paulo, Brazil, ${ }^{6}$ National Institute of \\ Science and Technology in Oncogenomics and Therapeutic Innovation, São Paulo, Brazil
}

The immune system plays a crucial role in cancer development either by fostering tumor growth or destroying tumor cells, which has open new avenues for cancer immunotherapy. It was only over the last decade that the role of B cells in controlling anti-tumor immune responses in the tumor milieu has begun to be appreciated. B and

OPEN ACCESS

Edited by:

Adriana Franco Paes Leme,

Brazilian Biosciences National

Laboratory (LNBio), Brazil

Reviewed by:

Gaofeng Xiong,

University of Kentucky, United States

Dong-Joo (Ellen) Cheon,

Albany Medical College, United States

*Correspondence:

Tiago da Silva Medina tiago.medina@accamargo.org.br

${ }^{\dagger}$ These authors have contributed equally to this work

Specialty section:

This article was submitted to Molecular Medicine,

a section of the journal

Frontiers in Cell and Developmental

Biology

Received: 08 March 2021 Accepted: 27 April 2021

Published: 07 June 2021

Citation:

Kinker GS, Vitiello GAF, Ferreira WAS, Chaves AS, Cordeiro de Lima VC and Medina TS (2021) B Cell Orchestration of Anti-tumor Immune Responses: A Matter of Cell

Localization and Communication. Front. Cell Dev. Biol. 9:678127. doi: 10.3389/fcell.2021.678127 plasma cells can exert anti-tumor effects through antibody-dependent cell cytotoxicity (ADCC) and activation of the complement cascade, even though their effector functions extend beyond the classical humoral immunity. In tumor tissues, B cells can be found in lymphoid aggregates, known as tertiary lymphoid structures (TLSs), well-organized non-encapsulated structures composed of immune and stromal cells. These structures reflect a process of lymphoid neogenesis occurring in peripheral tissues upon longlasting exposure to inflammatory signals. The TLS provides an area of intense B cell antigen presentation that can lead to optimal $T$ cell activation and effector functions, as well as the generation of effector B cells, which can be further differentiated in either antibody-secreting plasma cells or memory B cells. Of clinical interest, the crosstalk between $\mathrm{B}$ cells and antigen-experienced and exhausted $\mathrm{CD}^{+} \mathrm{T}$ cells within mature TLS was recently associated with improved response to immune checkpoint blockade (ICB) in melanoma, sarcoma and lung cancer. Otherwise, B cells sparsely distributed in the tumor microenvironment or organized in immature TLSs were found to exert immune-regulatory functions, inhibiting anti-tumor immunity through the secretion of anti-inflammatory cytokines. Such phenotype might arise when B cells interact with malignant cells rather than $T$ and dendritic cells. Differences in the spatial distribution likely underlie discrepancies between the role of B cells inferred from human samples or mouse models. Many fast-growing orthotopic tumors develop a malignant cell-rich bulk with reduced stroma and are devoid of TLSs, which highlights the importance of carefully selecting pre-clinical models. In summary, strategies that promote TLS formation in close proximity to tumor cells are likely to favor immunotherapy responses. Here, the cellular and molecular programs coordinating B cell development, activation and organization within TLSs will be reviewed, focusing on their translational relevance to cancer immunotherapy.

Keywords: B lymphocytes, tertiary lymphoid structures, germinal center, T lymphocytes, tumor, anti-tumor responses, pro-tumor responses 


\section{INTRODUCTION}

Cancer arises from the accumulation of genetic mutations that ultimately lead to global epigenetic changes within transformed cells. These genetic and epigenetic alterations can potentially give rise to neoantigens whose recognition by the immune system is fundamental for tumor control. In particular, $\mathrm{CD}^{+} \mathrm{T}$ cells exert potent anti-tumor activities through the recognition of tumor neoantigens presented on class I major histocompatibility complex (MHC-I) molecules. However, when governed by an immunosuppressive microenvironment, immune cells may seed a fertile niche for tumor growth (Jones et al., 2019). Among the established hallmarks of cancer, tumor-promoting inflammation and tumor evasion from the immune response have emerged as important processes for cancer development and progression (Hanahan and Weinberg, 2011). The recognition that the immune system can counterintuitively be involved in either cancer development or control, depending on the milieu, represented a milestone in cancer research and has led to significant breakthroughs in clinical care for a growing list of malignancies (Farkona et al., 2016).

The field of immuno-oncology, however, is not as new as one might think: evidence demonstrating that the immune system is capable of eliminating tumors dates back to the early civilizations, when historical reports have documented spontaneous regression of tumors associated with concomitant infections and fever. In the nineteenth century, Rudolf Virchow was the first pathologist to observe the presence of inflammatory cells in solid tumors. Later, William Coley's pioneering empirical work reported tumor shrinkage in cancer patients who had severe postoperative infections. This groundbreaking observation led him to inoculate Streptococcus pyogenes into tumors to promote inflammation and tumor regression. Reaching the 1950s and 1960s, transplantation of chemically induced tumors between syngeneic animals pointed to the existence of anti-tumor-specific immunity endowed with memory (Dobosz and Dzieciatkowski, 2019).

Since then, leveraged by the outstanding technical and scientific progress made in molecular biology and immunology, the mechanisms behind tumor recognition by the immune system have been dissected (Dobosz and Dzieciatkowski, 2019). Over the past years, cytotoxic $\mathrm{CD}^{+} \mathrm{T}$ lymphocytes have been in the center of this debate, as their anti-tumor response can optimally eliminate tumor cells by specifically recognizing tumor antigens that originate from mutated or aberrantly expressed proteins linked to MHC-I on the surface of tumor cells (Schumacher and Schreiber, 2015).

Further advances in immunology have helped to elucidate why $\mathrm{CD}^{+} \mathrm{T}$ cells often fail to efficiently control the development of cancer, revealing that immune regulatory mechanisms operate in the cancer milieu. The inflammatory counterbalance promoted by immune regulatory mechanisms is essential to prevent undesirable local tissue damage. Accordingly, multiple immune regulatory processes can be induced in the tumor microenvironment and include, but are not limited to, suboptimal priming of lymphocytes by immature dendritic cells maintained in the absence of inflammatory signals, tolerance mechanisms triggered by autoantigens expressed in tumor cells, as well as $\mathrm{T}$ cell exhaustion due to chronic antigenic stimulation (van der Leun et al., 2020). This accumulated knowledge paved the way for the development of several therapies aimed to overcome these barriers, including cytokine therapies, cellular vaccines employing ex-vivo activated dendritic cells, and immune checkpoint blockade (ICB) therapies, which are currently approved for several types of cancers (Zhang and Zhang, 2020).

Despite the major impact that immunotherapies, specially ICB, have had on cancer treatment, several challenges still persist for their widespread application, as evidenced by the significant number of patients that do not derive clinical benefits and the cancer types wherein their efficacy is still to be proved. Thus, further clarification of the immune mechanisms operating in the tumor microenvironment is needed in order to identify novel therapeutic targets and biomarkers of response (Gibney et al., 2016; Bai et al., 2020).

As previously highlighted, cytotoxic T lymphocytes, thought to be the major effector cells in anti-tumor immune responses, have received the greatest attention throughout the history of the immuno-oncology field. However, more recently it has become apparent that these cells are not capable of acting independently, relying on a complex network of interactions with other immune and stromal cells for their coordinated activation, maintenance and function (Garner and de Visser, 2020). In this context, the pivotal role of $\mathrm{B}$ lymphocytes on anti-tumor immune responses has only begun to be appreciated. These cells can mediate both pro-and anti-tumor effects and perform a plethora of roles in the tumor milieu, such as secretion of antibodies and cytokines, antigen presentation for both cytotoxic $\left(\mathrm{CD}^{+}\right)$and helper $\left(\mathrm{CD}^{+}\right) \mathrm{T}$ lymphocytes, and coordination and maintenance of lymphoid aggregates known as tertiary lymphoid structures (TLS), which are privileged sites for antigen presentation and $\mathrm{T}$ cell (re-)activation (Sautes-Fridman et al., 2019; Sharonov et al., 2020).

In this review, we outline the multiple functions of $\mathrm{B}$ lymphocytes in anti-tumor immune responses. In particular, we briefly describe B cell biology from genesis to effector functions. We also discuss the spatial organization of $\mathrm{B}$ cells in the tumor microenvironment, highlighting the molecular mechanisms that promote $\mathrm{B}$ and $\mathrm{T}$ cell compartmentalization within TLSs in chronic inflammatory processes, focusing mainly on cancer. We then present evidence for both pro-and anti-tumor responses of $\mathrm{B}$ cells depending on what cellular niche these cells occupy. We also describe how the spatial organization within TLS can shape antitumor effector $\mathrm{B}$ and $\mathrm{T}$ cell responses and we provide evidence that mature TLSs are an ideal environment capable of triggering optimal T cell activation, which ultimately leads to the expression of clinically relevant immune checkpoints.

\section{B LYMPHOCYTE BIOLOGY: FROM B CELL ONTOGENY TO ACTIVATION AND ITS ROLE IN ANTIGEN PRESENTATION}

B lymphocytes are the main cellular components of the humoral compartment of adaptive immunity (Sebina and Pepper, 2018). Their development occurs mainly in the liver during fetal life and 
in the bone marrow (BM) after birth through several sequential steps of differentiation, wherein hematopoietic stem cells (HSCs) reach the common lymphoid progenitor (CLP) stage, which gives rise to either B, T or Natural Killer (NK) cells (Rieger and Schroeder, 2012). B lymphocytes derived from the fetal liver belong to the B-1a lineage and comprise a population of longlived and self-renewing B lymphocytes that occupy body cavities and mucosae and constitutively secret IgM antibodies ("natural antibodies") of restricted specificity (Baumgarth, 2017). The vast majority of $\mathrm{B}$ lymphocytes in adults is derived from the BM and can be divided into the B-1b lineage, which are functionally similar to B-1a cells, and the B-2 lineage, which migrate from the $\mathrm{BM}$ to the spleen to further differentiate into marginal-zone or follicular B lymphocytes (Pieper et al., 2013).

The ontogeny of lymphocytes initiates with the differentiation of HSCs into a lymphoid-primed multipotent progenitor (LMPP), which expresses the lymphoid-specific recombinases RAG1 and RAG2 that promote LMPP differentiation into the earliest lymphoid progenitor (ELP) and then into CLPs. In mice, the commitment of the $\mathrm{B}$ cell lineage is critically dependent on the expression of the cytokine receptors FLT3 and IL-7R (Medina and Singh, 2005), while IL-7 signaling does not seem to be essential in humans (Pieper et al., 2013).

The early transcription factors (TFs) involved in B lymphocyte commitment, E2A and EBF, act coordinately to repress key molecular programs from other cell lineages and promote the expression of PAX5, which further stabilizes lineage commitment, thus defining the pro-B stage (Sigvardsson, 2018). Next, developing B cells begin to mount their antigen specific $\mathrm{B}$-cell receptors (BCR) that are constituted by accessory signaling proteins coupled to transmembrane isoforms of IgM antibodies. These are composed of two heavy chains generated through recombination between variable regions $\left(\mathrm{V}_{\mathrm{H}}, \mathrm{D}_{\mathrm{H}}\right.$, and $\left.\mathrm{J}_{\mathrm{H}}\right)$ from the Ig heavy $(\mathrm{H})$ locus, each combined with a light chain, generated through recombination between variable regions VL and JL from Ig $\kappa$ or $\lambda$ light (L) chain loci (Jung and Alt, 2004). This process generates approximately $5 \times 10^{13} \mathrm{~B}$ lymphocyte clones, each expressing a unique BCR that recognizes a different epitope (Pieper et al., 2013).

Initially, E2A and EBF1 direct RAG1 and RAG2 recombinases to the IgH locus in pro- $\mathrm{B}$ cells, promoting $\mathrm{D}_{\mathrm{H}}-\mathrm{J}_{\mathrm{H}}$ recombination (Romanow et al., 2000). Then, $\mathrm{V}_{\mathrm{H}}-\mathrm{DJ} \mathrm{J}_{\mathrm{H}}$ recombination is facilitated by PAX5-promoted "contraction" of IgH locus (Fuxa et al., 2004; Jung et al., 2006). The terminal deoxynucleotidyl transferase $(\mathrm{TdT})$ is specifically expressed during this phase and further increases the junctional diversity by adding random nucleotides in recombination sites (Bertocci et al., 2006). After recombination, IgH forms a complex with the polypeptide chains $\mathrm{V}$ Pre-B and $\lambda 5$, which substitute the Ig light chain. $\operatorname{IgH}$ also interacts with $\operatorname{Ig} \alpha$ (CD79a), and $\operatorname{Ig} \beta$ $(\mathrm{CD} 79 \mathrm{~b})$, giving rise to the pre-BCR, whose expression is regulated by the key TFs that characterize the pre- $B$ stage (Sigvardsson, 2018).

The correct assembly of pre-BCR represents an important checkpoint for B cell development. This receptor signals through the Burton's tyrosine kinase (BTK) and the adapter protein BLNK to promote cell survival, proliferation and activation of the TFs NF- $\kappa$ B and interferon response factor 4 (IRF4), which have been shown to be essential for the rearrangement of IgL chains. The recombination events are initiated in Ig $\kappa$ locus and followed by $\lambda$ locus if $\kappa$ rearrangements for both alleles result in a non-functional or self-reactive BCR (Pieper et al., 2013; Sigvardsson, 2018). Complex molecular mechanisms ensure that Ig rearrangements for $\operatorname{IgH}$ and $\operatorname{IgL}$ occur at one allele at a time, promoting the usage of the other allele only if the first recombination is unproductive. The mechanisms behind this process, named allelic exclusion, are not yet fully understood (Vettermann and Schlissel, 2010).

Developing B cells that successfully produce non-selfreactive BCRs undergo molecular changes including a decrease in the chemokine receptor CXCR4 signaling (Beck et al., 2014) and an increase in the expression of sphingosine-1phosphate receptor 1 (S1P1) (Cinamon et al., 2004), which mediate the migration of $B$ cells to the spleen, where they complete their maturation to marginal zone or follicular $\mathrm{B}$ cells, depending on the strength of BCR signaling to selfantigens and NF-кB, BAFF, and Notch2 signaling pathways (Pillai and Cariappa, 2009). Marginal-zone B cells remain on the spleen mediating mainly T-independent responses to blood-borne antigens from diverse chemical natures (proteins, lipids, carbohydrates); whereas follicular B cells migrate through B-cell zones (or follicles) in lymph nodes throughout the body, guided by the interaction between CXCR5, expressed on their cell surface, and CXCL13, a chemokine produced by follicular dendritic cells (FDCs). Then, the encounter between naïve B lymphocytes and their cognate antigens, either captured from peripheral tissues by FDCs or freely borne through lymph, is favored in follicular B-cell zones (Cyster and Allen, 2019).

As part of the innate immune response, complement systemderived peptides can bind to the surface of pathogens/antigens. FDCs capture complement-covered pathogens and antigens in peripheral tissues through complement-specific receptors present on their cell membranes and transport them to lymph nodes. In follicles, BCR interacts with surface antigens, and high-affinity interactions promote both BCR signaling and internalization of the bound antigen through a clathrin-dependent mechanism. Activation of co-receptors on B cell surface, such as complement receptors and pathogen-associated molecular pattern recognition receptors, such as Toll-like receptors (TLRs), amplifies BCR signaling and diminishes the B cell activation threshold, while inhibitory receptors that recognize self-molecules, such as CD22, or antibodies, such as Fc $\gamma$ RIIb, may increase the threshold for $\mathrm{B}$ cell activation, acting as a negative feedback to prevent auto-reactivity and exacerbated immune responses (Cyster and Allen, 2019).

As a consequence of early B cell activation, these cells downregulate the expression of $\mathrm{S} 1 \mathrm{P} 1$ and begin to express CCR7 and EBI2, which direct them to the interface between $\mathrm{B}$ cell follicles and adjacent $\mathrm{T}$ cell zones, following CCL21 and CCL19 gradients. In parallel, these cells process the internalized antigen to present antigen-derived peptides bound to MHCII on their cell surface along with co-stimulatory ligands, such as CD80/CD86 and ICOSL. Altogether, these phenotypic 


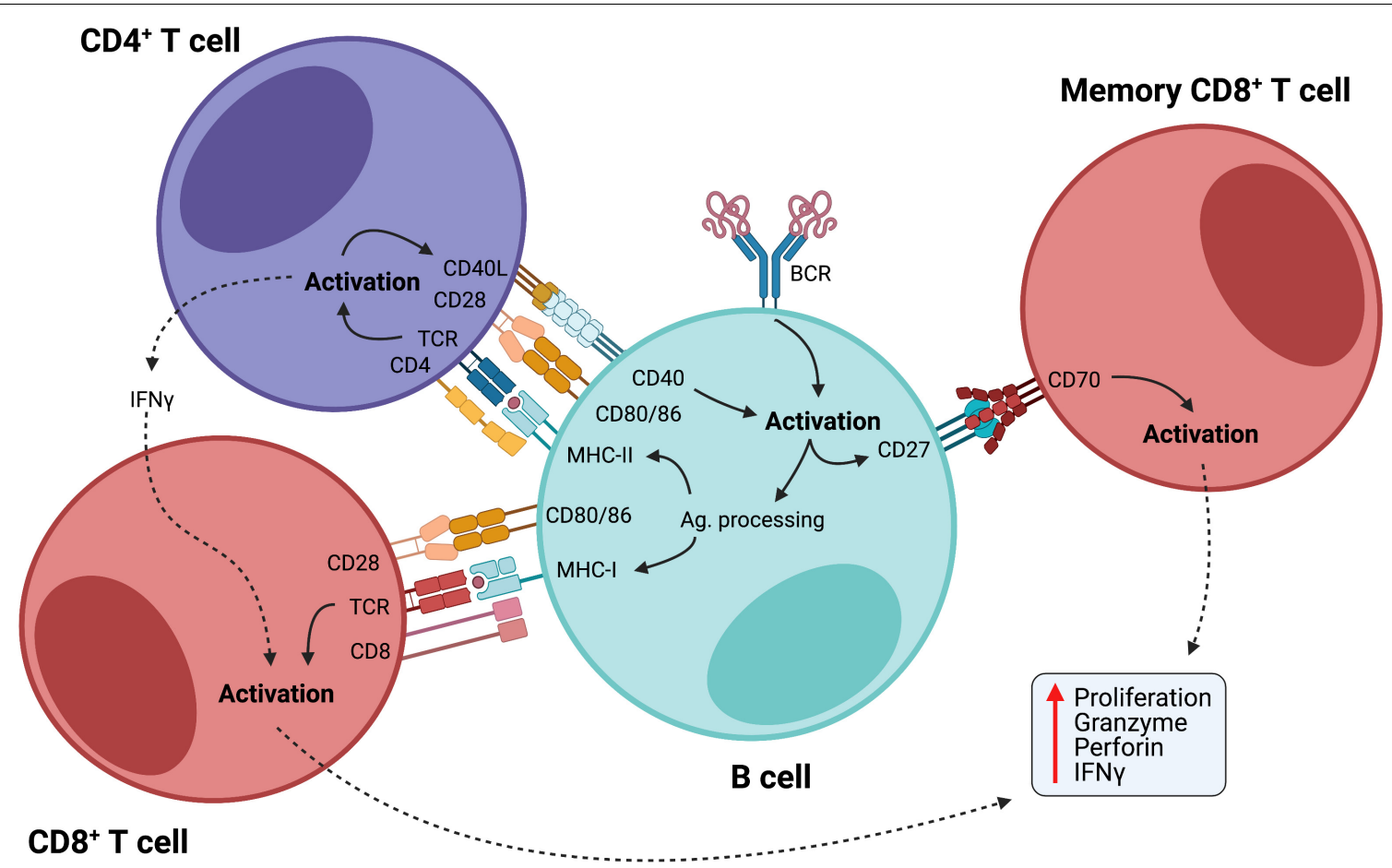

FIGURE 1 | B cells as activators of cellular immunity. B cells are initially activated by antigen recognition through BCR. Internalized antigens are then presented through class II MHC to CD4+ helper T cells, which provide co-stimulatory signals for B cell activation. Activated B cells acquire enhanced potential for antigen presentation with upregulation of $\mathrm{MHC}-\mathrm{I}$ and II and co-stimulatory molecules, such as CD80/86, further activating both CD4 ${ }^{+}$and $\mathrm{CD} 8^{+} \mathrm{T}$ cells. Also, CD27 is upregulated in activated B cells, and interaction between this molecule and CD70 on the membrane of memory CD8 ${ }^{+} \mathrm{T}$ cells promotes their maintenance and facilitates their activation in an antigen-independent manner. CD8 ${ }^{+} \mathrm{T}$ cell activation leads to efficient cell proliferation and production of potent inflammatory mediators, such as granzymes, perforin, and IFN- $\gamma$.

changes favor B cell interaction with activated $\mathrm{CD} 4^{+}$helper $\mathrm{T}$ cells migrating in the opposite direction. The recognition of MHC-II-bound peptides by $\mathrm{CD}^{+} \mathrm{T}$ cells along with costimulatory signals promote their activation and differentiation into follicular-helper $\mathrm{T}$ cells $\left(\mathrm{T}_{\mathrm{FH}}\right)$, which express $\mathrm{CD} 40 \mathrm{~L}$, that interact with CD40 on B cells. This intimate B-T cell interaction in the presence of cytokines, such as IL-4 and IL-21, promotes B cell survival, proliferation and activation (Cyster and Allen, 2019).

Activated B cells also undergo class-switch recombination (CSR), in which the conserved region of expressed antibodies is changed from those derived from $\mathrm{C} \mu$ and $\mathrm{C} \sigma$ loci to those coded by $\mathrm{C} \gamma, \mathrm{C} \alpha$, or $\mathrm{C} \varepsilon$ loci. This allows the replacement of $\operatorname{IgM}$ and $\operatorname{IgD}$ by $\operatorname{IgG}$, IgA, or IgE, depending on the inflammatory stimulus. Each conserved region holds different effector functions and is induced by different cytokines secreted by $\mathrm{T}_{\mathrm{FH}}$ cells. For instance, IFN- $\gamma$ promotes IgG2a and IgG3 production, while IL-4 facilitates switching to IgE, and TGF$\beta$ favors IgA (Zhang, 2003). CSR is depends on the activated induced deaminase (AID) expressed in B cells, which also promotes hypermutation of the Ig variable region, further increasing antibody diversification and affinity maturation in a clonal fashion (Cyster and Allen, 2019).

In summary, B cells capture, process and present antigens to $\mathrm{CD}^{+} \mathrm{T}$ cells, what may lead to mutual activation. Once activated, B cells undergo proliferation while changing their antibody repertoire by inducing class-switching and affinity maturation. This drives the development of a germinal center (GC), composed of a "dark zone" (DZ), where B cells interact with $\mathrm{T}_{\mathrm{FH}}$ cells and undergo activation and clonal expansion, and a "light zone" (LZ), characterized by cells derived from the DZ undergoing CSR and affinity maturation. In the LZ, cells that effectively produce high-affinity antibodies differentiate either into antibody-secreting plasma cells or memory B cells (Gatto and Brink, 2010).

The ability of B cells to efficiently present antigens and activate $\mathrm{T}$ cells through the expression of co-stimulatory molecules is of particular interest, as a large body of evidence has shown that B cells can present antigens as efficiently as professional APCs, such as dendritic cells, and promote $\mathrm{T}$ cell mediated immune responses in various contexts (Rivera et al., 2001; Chen and Jensen, 2008; de Wit et al., 2010; Adler et al., 2017; Hong et al., 2018), including cancer (Nielsen et al., 2012; Rossetti et al., 2018), where B cells demonstrated high capacity of cross-presenting internalized antigens via MHC-I to activate cytotoxic T cells (Gnjatic et al., 2003). Additionally, the interaction between CD27-expressing $\mathrm{B}$ cells and CD70-expressing $\mathrm{CD} 8^{+} \mathrm{T}$ lymphocytes induces cytotoxic $\mathrm{T}$ cell responses in an antigen-independent manner (Deola et al., 2008), demonstrating another way by which B cells stimulate $\mathrm{T}$ cell responses (Figure 1). 


\section{SECONDARY LYMPHOID ORGANS AND TERTIARY LYMPHOID STRUCTURES: FUNCTIONALLY SIMILAR, BUT SLIGHTLY DIFFERENT IN COMPOSITION}

The formation of TLSs is a phenomenon associated with chronic inflammatory conditions, such as autoimmune diseases and cancer, reflecting a process of lymphatic neogenesis that creates a local hub for antigen presentation and immune responses (Pitzalis et al., 2014). Though the main cellular components of TLSs are lymphocytes and dendritic cells, the adequate organization of this complex environment is sustained by a network of non-hematopoietic stromal cells. Populations of lymphatic and blood endothelial cells and immunofibroblasts are at the core of this framework (Buckley et al., 2015).

Key steps involved in the formation of secondary lymphoid organs (SLOs) during organogenesis are also commonly observed in the formation of TLSs. However, while SLO development occurs in predefined areas during embryogenesis, TLSs are ectopically formed at sites of chronic inflammation. A crucial step for the fetal development of the secondary lymphoid tissue is the migration of integrin $\alpha 4 \beta 7^{+}$lymphoid tissue inducer cells (LTis) that interact with MadCAM- $1^{+}$high endothelial venules (HEVs) in the lymph node anlagen (Mebius et al., 1996). LTis originate from common lymphoid progenitors in the fetal liver and undergo maturation through a process involving the Notch signaling pathway and the transcriptional repressor Id2. This generates terminally differentiated LTis expressing ROR $\gamma \mathrm{T}$ and $\alpha 4 \beta 7$ integrin (Cherrier et al., 2012). Retinoic acid produced by nerve endings allows mesenchymal cells to express the chemokine CXCL13, whose gradient attracts LTis via interaction with the receptor CXCR5. Although both CXCL13 and CCL21 chemokines have the capacity of attracting LTis during the early embryonic phases, only CXCL13 is expressed in all lymph node anlagen at that time (van de Pavert et al., 2009).

Once properly recruited to the anlagen, LTis activate stromal lymphoid tissue organizer cells (LTos) through the interaction between the lymphotoxin (LT) $\alpha 1 \beta 2$ and its receptor, LT $\beta$ R. This favors the expression of several adhesion molecules by LTos, such as VCAM-1, ICAM-1, and MadCAM-1, which, together with the homeostatic chemokines CCL19, CCL21, and CXCL13, promotes the recruitment of lymphocytes and the retention of LTis (Peduto et al., 2009; Vondenhoff et al., 2009). Another interesting point is that while chemokines promote the recruitment of DCs, NK, $\mathrm{T}$ and $\mathrm{B}$ cells, LT $\beta \mathrm{R}$ signaling aids the development of lymph nodes, as well as cell clustering and spatial organization. LTos develop further into follicular (FC) and fibroblastic reticular cells (FRC) that provide the conduit framework on which $\mathrm{T}$ and $\mathrm{B}$ cells migrate and interact with each other, allowing the proper development of adaptive immunity (Veiga-Fernandes et al., 2007; van de Pavert et al., 2009).

Much of the current knowledge about TLS formation and function comes from murine models of autoimmunity (Pipi et al., 2018). In human Sjogren's Syndrome (SS) and murine models of SS, TLS assembly is strictly dependent on a network of gp $38^{+}$ immunofibroblasts that are phenotypically and functionally similar to FRC networks in SLO. In both cases, the coordinated action of IL-22, LT $\alpha 1 \beta 2$, and Th2 cytokines seems to be associated with such network formation. Although lymphocytes are not needed for the priming of immunofibroblast progenitors, they contribute for the network expansion and activation. While ROR $\gamma \mathrm{T}^{+}$LTis play a critical role in the development of fibroblast reticular cells in SLOs, they are not required for priming and expansion of TLS immunofibroblasts in SS (Nayar et al., 2019). Of note, IL-21-producing Th17 cells might work as LTi cells that initiate TLS organogenesis and GC formation (Deteix et al., 2010). A murine model of experimental autoimmune encephalomyelitis (EAE) demonstrated that gp $38^{+}$Th17 cells stably producing Th17 cytokines induce the expression of CXCL13 in the central nervous system and the development of follicle-like structures (Peters et al., 2011). These structures were composed of B cell clusters, surrounded by a mantle of T cells and collagen fibers; the latter could extend into the center of B cell clusters. Moreover, the expression of GC markers GL7 and PNA revealed the existence $B$ cell aggregates with different levels of maturation.

\section{Germinal Center Maturation in Chronically Inflamed Scenarios}

So far, we have presented a sketch of the TLS structure, briefly pointing out what makes them different from SLOs. However, we have not delved into a particular aspect, common to both structures, that may draw special attention: the GC maturation (Figure 2). Classical markers of GC B cells include lack of surface IgD, upregulation of CD38, high expression levels of Fas and n-glycolylneuraminic acid, along with the selective expression of BCL-6 and AID. When mature, GCs constitute well-structured regions with two dynamic compartments: the DZ and LZ. The gradient of CXCL12 and CXCL13, along with the expression of their respective receptors CXCR4 and CXCR5, dictates the spatial distribution of B cells. During the events taking place into GCs, activated B cells acquire new features and functions. The CXCR4expressing centroblasts are mostly located in the DZ, due to the CXCL12 abundance, whereas the CXCR5-expressing centrocytes move to the LZ, in favor of the CXCL13 gradient (Gatto and Brink, 2010). Besides moving through the GC zones in response to a chemokine gradient, B cells can also be engaged in short, dynamic interactions with both $\mathrm{T}$ cells and antigens.

This whole process can be observed in well-structured TLS, as they are analogous in structure and function to SLOs (Germain et al., 2014). In immature TLSs, on the other hand, B cells cannot interact and expand properly, hampering the formation of active GCs. Indeed, in early steps of hepatocellular carcinoma progression, immature TLSs are associated with inefficient immune responses and tumor evasion (Meylan et al., 2020). Maturation of murine TLSs can be induced by LT-producing B cells, as it has been shown that the reconstitution of $\mathrm{LT}^{-/-}$ recipients with bone marrows containing LT-producing B cells was critical for skewing immature TLSs into mature TLSs (Lorenz et al., 2003; McDonald et al., 2005).

In colorectal cancer, multi-parameter immunofluorescence detection of CD21, CD23 and CXCL13 revealed three different 


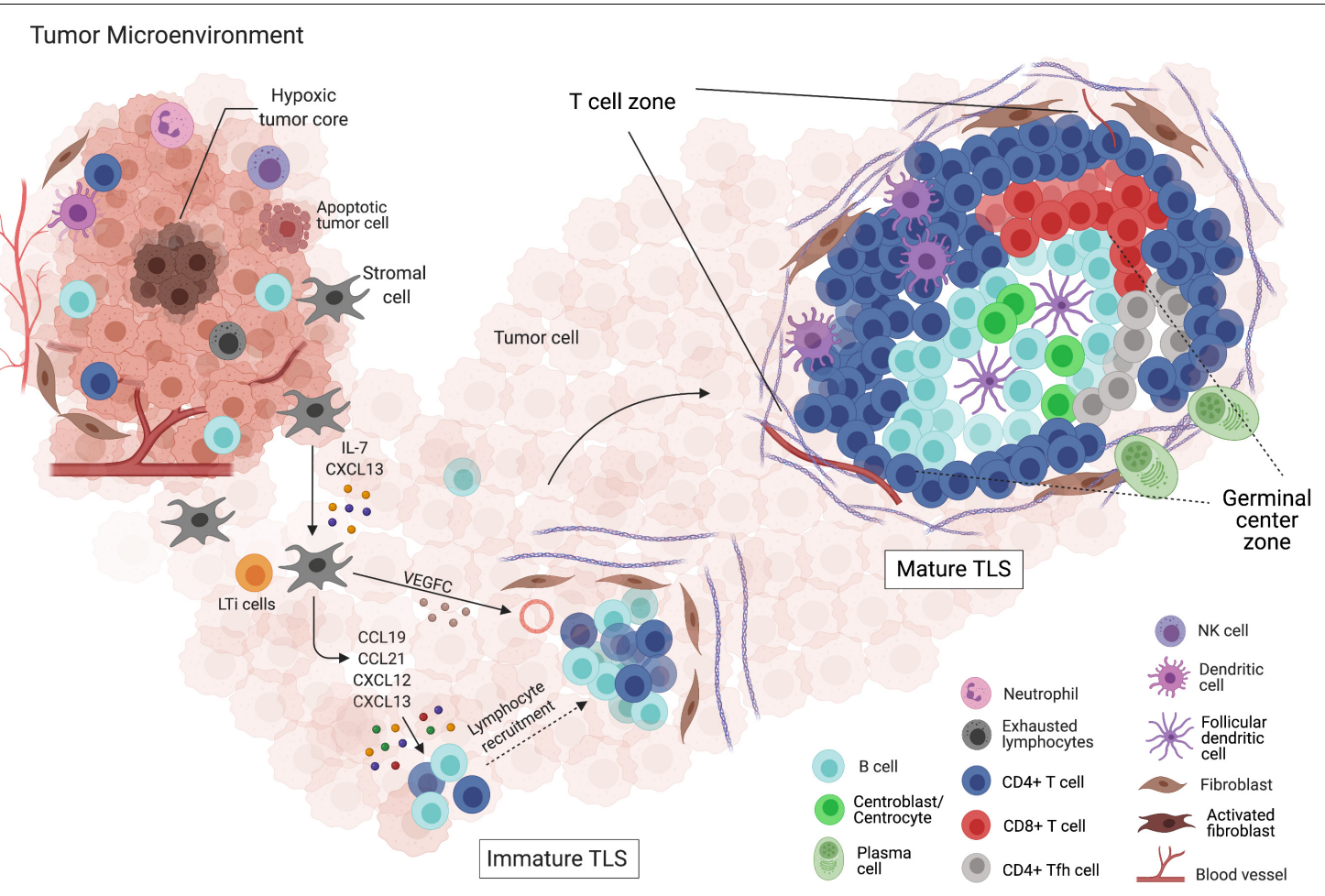

FIGURE 2 | Formation and maturation of tertiary lymphoid structures (TLSs) within the tumor microenvironment. (I) Depiction of the tumor microenvironment and its interactions with both innate and adaptive immune cells, and the non-immune components. (II) LTis attracted by the CXCL13 gradient, produced by activated stromal cells, migrate to the site of TLS initiation. Chemokines, such as CCL19, CCL21, CXCL12, and CXCL13, allow the migration and retention of additional LTis along with lymphocytes. The gathering of leukocytes surrounded by an extracellular matrix net produced by fibroblasts and newly formed blood vessels supports immature TLS formation, which fails to mount effective anti-tumor responses. (III) The presence of clearly delimited T cell and B cell zones, as well as a GC-like structure, defines mature TLSs. In this structure, the induction of plasma cells and memory B cells takes place, reflecting the interaction with other specific cell types, such as FDCs, $T_{F H}$, and CD8 ${ }^{+} T$ cells. Surrounded by pericytes and expressing adhesion molecules, the normal high endothelial venules (HEVs) located at the TLS vicinity favor the formation of mature TLSs, which are thought to be a rich niche of anti-tumor B and T cell responses.

states of TLS maturation: (i) early TLS as dense lymphocytic aggregates; (ii) primary follicle-like TLS, composed of $\mathrm{B}$ cell clusters with FDC networks, but devoid of GCs; and (iii) the secondary follicle-like TLS, including active GCs with $\mathrm{CD}^{+} 3^{+} \mathrm{B}$ cells (Posch et al., 2018). In melanoma samples, mature GCs composed of highly proliferative $\mathrm{KI}_{67}{ }^{+}$ $B$ cells were associated with higher frequencies of antigenexperienced $\mathrm{CD} 4^{+} \mathrm{T}$ cells expressing the anti-apoptotic molecule BCL2 (Cabrita et al., 2020). Such structures also included $\mathrm{TCF}^{+} \mathrm{IL7R}^{+}$naive and/or memory $\mathrm{CD}^{+}$and $\mathrm{CD}^{+} \mathrm{T}$ cells. In a cohort of esophago-gastric primary adenocarcinomas, approximately $48 \%$ of patients presented TLSs along the tumor invasive margin, as well as tumor-specific antibodies in the serum, underscoring the presence of B cell-dependent antitumor responses (Schlosser et al., 2019). In line with these observations, $\mathrm{CD}^{+}{ }^{+} \mathrm{CD} 4{ }^{+} \mathrm{CCR}^{-}{ }^{-} \mathrm{CD} 45 \mathrm{RA}^{-} \mathrm{CXCR}^{+} \mathrm{T}_{\mathrm{FH}}$ cells and $\mathrm{CD}_{20}{ }^{-} \mathrm{CD} 27^{+} \mathrm{CD} 38^{+}$plasmablasts were found to be enriched in tumor samples compared to peripheral blood. Interestingly, the number of $\mathrm{B}$ cells was reduced in the microenvironment of tumors that expressed PD-L1 or lacked the expression of HLA-I (Schlosser et al., 2019).

In autoimmune diseases, spontaneous GC development often contributes to the disease severity due to self-reactive
B cells (Domeier et al., 2017). In this case, IFN- $\gamma$ plays a major role through its signaling pathway, as IFN $\gamma \mathrm{R}$ signaling phosphorylates STAT1 and upregulates T-bet in B cells, which is required for spontaneous $\mathrm{GC}$ formation and class switching to IgG2b and IgG2c antibodies (Domeier et al., 2016). A different perspective can be seen in the context of chronic infectious diseases. In a C57BL/6 mouse model of Mycobacterium tuberculosis infection with $\mathrm{H} 37 \mathrm{Rv}$ or HN878 strains (Hertz et al., 2020), sex affected the appropriate formation of B cell follicles upon infection, as chronically $\mathrm{H} 37 \mathrm{Rv}$-infected male mice expressed diminished levels of CXCL13 and CCL19 in the lungs, in comparison with female mice. Besides, when HN878 strain infection developed, there was a significantly higher amount of IL-17A, IL-23, and IL-1 $\beta$ in female lungs (Hertz et al., 2020). Perhaps in this scenario, sex differences between hosts and their genetic background may impact the assembly of mature TLSs (Hertz and Schneider, 2019). In a Helicobacter pylori infection model, CXCR5 ${ }^{-/}$mice failed to induce the formation of TLSs and Peyer's patches, which generated less antigen-loaded DCs, diminished $\mathrm{T}$ cell priming and impaired $\mathrm{T}$ cell-dependent $\mathrm{B}$ cell response against the pathogen (Winter et al., 2010).

But what should be expected when cancer-related scenarios are considered? We will next explore in detail the biological and 
clinical relevance of the spatial organization of B cells in different types of tumors. We will also speculate how this system may be exploited clinically to improve patient prognosis and responses to immunotherapy.

\section{PRO-TUMOR FUNCTIONS OF B LYMPHOCYTES}

Our understanding of the multifaceted functions of $\mathrm{B}$ lymphocytes in tumor immunity has improved substantially in recent years. Current evidence suggests that the tumor microenvironment may have distinct B cell subpopulations that can exert both pro- or anti-tumor activities (Germain et al., 2014; Shimabukuro-Vornhagen et al., 2014; Shalapour et al., 2015; Wouters and Nelson, 2018; Figure 3), hence affecting patient outcomes (Mauri and Menon, 2017; Hu et al., 2019). The balance between the dual role of $\mathrm{B}$ cells is influenced by several factors, such as hypoxia (Caro-Maldonado et al., 2014; Shin et al., 2014; Meng et al., 2018), cytokines and metabolites produced by tumor cells (Wejksza et al., 2013; Pimenta et al., 2015; Ricciardi et al., 2015; Somasundaram et al., 2017; Ye et al., 2018), other immune cells [e.g., regulatory T cells (Tregs) and myeloid-derived suppressor cells (MDSC); Zhao et al., 2006; Shen et al., 2018; Wang Y. et al., 2018], inhibitory factors produced by B cells (Kessel et al., 2012; Khan et al., 2015; Shalapour et al., 2015) and immune checkpoints (Nishimura et al., 1998; Okazaki et al., 2001; Haas, 2011; Escors et al., 2018).

When outside the TLS, B cells can acquire a plethora of suppressive functions, meaning that $\mathrm{B}$ cell spatial distribution across the tumor microenvironment influences their activities. Thus, it is tempting to speculate that B cells acquire proinflammatory features that fully activate $\mathrm{T}$ cell responses when compartmentalized within TLS, while B cells outside the TLS are likely to acquire anti-inflammatory features that contribute to tumor growth (Cabrita et al., 2020). Within TLSs, it is possible that the mantle of $\mathrm{T}$ cells physically protects $\mathrm{B}$ cells from immunosuppressive stimuli found in the tumor tissue. The recent advent of technical approaches capable of interrogating the spatial architecture of tumor tissues (e.g., spatial transcriptomics) will allow the detailed exploitation of the TLS composition and function (Vickovic et al., 2019). Therefore, identifying strategies that reconfigure the spatial architecture of immune cells in the tumor microenvironment might have a great impact on the outcome of cancer patients.

Several studies have provided solid evidence that the tumorpromoting effects are mainly led by a diverse population of B cells known as regulatory B cells (Breg) (Schwartz et al., 2016; Sarvaria et al., 2017; Matsushita, 2019; Sharonov et al., 2020; Wang et al., 2020). Multiple Breg phenotypes that fulfill an immunosuppressive role have been described in different human solid tumors (Lee-Chang et al., 2013; Shao et al., 2014; Zhou et al., 2014; Wang et al., 2015; Wei et al., 2016; Roya et al., 2020; Wu et al., 2020a), as well as in peritumoral tissues (Garaud et al., 2019), peripheral blood (Qian et al., 2015; Wang K. et al., 2018; Karim and Wang, 2019; Murakami et al., 2019) and tumor-draining lymph nodes (Ganti et al., 2015), suggesting their broad clinical relevance and potential therapeutic application. Nevertheless, due to intricate origins and activation pathways, there is still no clear consensus on Breg-cell-specific phenotypic or lineage commitment markers, and the transcription factors that specifically drive the development of these cells remain elusive (Oleinika et al., 2019; Wang et al., 2020).

In both human and mice, most studies of Bregs are concentrated in memory $\mathrm{CD}_{2} 7^{+}$and transitional $\mathrm{CD} 38^{+} \mathrm{B}$ cells, sharing markers such as $\operatorname{IgA}^{+} \mathrm{CD}_{138^{+}}$and $\operatorname{IgM}^{+} \mathrm{CD} 147^{+}$ with plasma cells (Fremd et al., 2013; Schwartz et al., 2016). Recently, a solution to this problem was proposed employing Toll-like receptor ligands, together with high dimensional dataanalysis (Chaye et al., 2021). The available data suggest that Breg cells can arise at various stages during B cell development and differentiation in response to various cues, including cytokines (e.g., IL-35, IL-21, IL-1 $\beta$, and IL-6) (Yoshizaki et al., 2012; Rosser et al., 2014; Wang et al., 2014; Dambuza et al., 2017), large amounts of calcium influx (Matsumoto et al., 2011; Matsumoto and Baba, 2013) and activation of surface molecules such as TLRs, CD40 and BCRs (Fillatreau et al., 2002; Yoshizaki et al., 2012; Rosser et al., 2014; Menon et al., 2016; Ran et al., 2020).

Breg cells support carcinogenesis, tumor progression and metastasis predominantly, although not exclusively, through the production of IL-10, TGF- $\beta$, and IL-35 or by intercellular contact (Ammirante et al., 2010; Shao et al., 2014; Tao et al., 2015; Wang et al., 2015; Schwartz et al., 2016; Xiao et al., 2016; Sarvaria et al., 2017). IL-10-producing Bregs can induce dendritic cells to produce IL-4 and downregulate IL-12, thereby affecting the Th1/Th2 balance (Moulin et al., 2000); they can suppress CD4 ${ }^{+}$ $\mathrm{T}$ cell differentiation into Th1 (suppressing IFN- $\gamma$ and TNF- $\alpha$ production) and Th17 (suppressing IL-17 production); they also suppress TNF- $\alpha$-producing monocytes (Iwata et al., 2011). Bregs can also induce the polarization of naïve $\mathrm{CD} 4^{+} \mathrm{T}$ cells into both FOXP3 $^{+}$Treg cells and IL-10-producing Tr1 cells, modulating cancer progression and increasing tumor metastasis (Olkhanud et al., 2011). Additionally, Bregs can promote apoptosis of effector $\mathrm{CD}^{+}{ }^{+} \mathrm{T}$ cells through the expression of FasL (Fillatreau et al., 2002; Iwata et al., 2011; Matsumoto et al., 2014; Wang et al., 2015; Zhou et al., 2016). Furthermore, IL-10-producing Breg cells have been shown to contribute to tumor progression by positively regulating the differentiation of tumor-associated macrophages (TAMs), skewed toward a M2 macrophage phenotype, that ultimately inhibit effector T and NK cells (Rosser et al., 2014; Wu et al., 2020b). It is currently unclear whether Bregs actively promote tumor growth, or an increase in the Breg population merely reflects the immune response against the tumor (Sarvaria et al., 2017).

Breg cells have also been reported to have other immunosuppressive mechanisms, such as (i) B cell expression of programmed cell death-1 (PD-1) via TLR4 activation, which induces $\mathrm{T}$ cell dysfunction and foster cancer progression; (ii) expression of other inhibitory molecules such as programmed death-ligand 1 (PD-L1) and FasL, which regulate humoral immunity mediated by $\mathrm{CD} 4^{+} \mathrm{CXCR} 5^{+} \mathrm{PD}-1^{+} \mathrm{T}_{\mathrm{FH}}$ cells via PD-1; (iii) combined secretion of IgG4 and IL-10; (iv) IL-21mediated induction of GZMB, which efficiently suppresses $\mathrm{T}$ cell proliferation by GrB-dependent TCR- $\zeta$ degradation; 

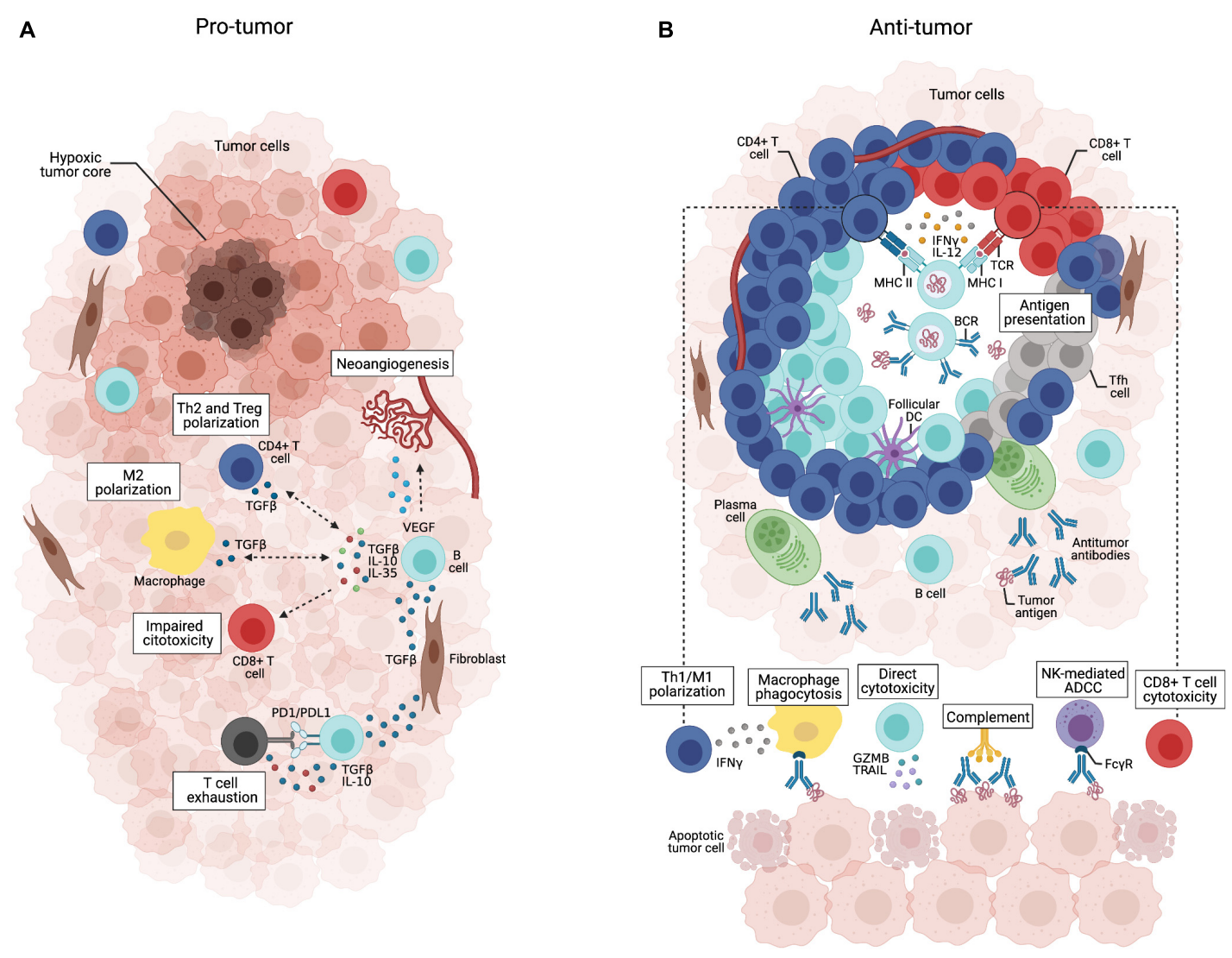

FIGURE 3 | Dual role of tumor-infiltrating B cells. (A) B cells scatteredly distributed throughout the tumor bulk may acquire immunosuppressive phenotypes in response to stimulation with TGF- $\beta$ secreted by fibroblasts, Tregs or M2 macrophages. They can release IL-10, IL-35, and TGF- $\beta$ that support Treg expansion and Th2/M2 polarization, while suppressing effector T cell activity, which is potentialized by B cell PD-L1 expression. VEGF-producing B cells may also promote tumor progression through neoangiogenesis.(B) Tumor-infiltrating B cells organized in well-structured TLSs coordinate anti-tumor immune responses through multiple mechanisms. They can present tumor-derived antigens to T cells and secrete cytokines such as IFN- $\gamma$ and IL-12 that support Th1/M1 polarization and CD8 ${ }^{+}$T cell cytotoxicity. Tumor-specific antibodies secreted by plasma cells can trigger the complement cascade, mediate phagocytosis of tumor cells, and antibody-dependent cell cytotoxicity by NK cells. Activated B cells may also directly kill tumor cells by secreting TRAIL and granzyme B.

(v) production of adenosine 5'-monophosphate (AMP) and adenosine (ADO), which suppresses activated $\mathrm{T}$ cells; (vi) activation of geranylgeranyl pyrophosphate (GGPP) (an intermediate of cholesterol metabolism), permitting transduction of signaling cascades necessary for IL-10 expression; (vii) production of indoleamine 2,3-dioxygenase (IDO), which inhibits T cell responses; (viii) expression of Aryl hydrocarbon receptor (AhR), which modulates the differentiation and function of Bregs, specially by suppressing their pro-inflammatory transcriptional program; and (ix) TLR4-mediated BCL6 upregulation that induces $\mathrm{T}$ cell dysfunction through $\mathrm{PD}-1$ expression and IL-10 secretion (Gotot et al., 2012; Lindner et al., 2013; Saze et al., 2013; van de Veen et al., 2013; Khan et al., 2015; Nouel et al., 2015; Ren et al., 2016; Xiao et al., 2016; Piper et al., 2019; Bibby et al., 2020). Furthermore, glioma cell-derived placental growth factors (PIGFs) have been shown to promote proliferation of intratumoral $\mathrm{B}$ cells by inducing their differentiation into TGF- $\beta$-producing Bregs that suppress CD8 T cell anti-tumor activities (Han et al., 2014).
Akin to murine studies, other human B cells are key mediators of tumor growth. In melanoma, gastric, lung, liver and prostate cancers, tumor-infiltrating B cells can persistently express VEGF (vascular endothelial growth factor) and other pro-angiogenic genes via STAT3 signaling, fostering tumor progression by increasing angiogenesis (Yang et al., 2013). Another subset of STAT3-activated B cells found in human prostate, non-small cell lung, and ovarian cancers, $\mathrm{CD}^{+}$ B cells promote tumor progression upon IL-6 activation (Zhang et al., 2016). Furthermore, IL35-producing B cells $\left(\mathrm{CD} 1 \mathrm{~d}^{\text {high }} \mathrm{CD}^{+}\right)$are required to support growth of early pancreatic neoplasia, more specifically KRAS $^{G 12 D}$-harboring neoplastic lesions (Pylayeva-Gupta et al., 2016). In addition, a hypoxic tumor microenvironment restrains the TLS formation and limits tumor elimination. Indeed, pancreas-specific hypoxiainducible factor $1 \alpha($ HIF $1 \alpha)$ deletion increased CXCL13 secretion and B-cell infiltration and was associated with accelerated tumor growth (Lee K.E. et al., 2016). This supports the idea that a compromised tumor microenvironment is likely to disrupt 
the spatial architecture of immune cells, largely perturbing the migration of immune cell populations and their organization in privileged sites, particularly TLSs, that elicit optimal activation and maintenance of anti-tumor immune responses. There is now great interest in understanding whether intratumoral perturbations, including aberrant neoangiogenesis, hypoxia, acidification, intense cell death by necrosis or apoptosis and fibrosis, could negatively impact TLS formation. Furthermore, $\mathrm{CD}^{+}{ }^{+} \mathrm{B}$ cells in metastatic ovarian carcinoma and CD20 ${ }^{+}$ and $\mathrm{CD}_{138^{+}} \mathrm{B}$ cells infiltration in epithelial ovarian cancer were associated with poor outcome (Dong et al., 2006; Lundgren et al., 2016). Taken together, a better understanding of immunosuppressive B cell subpopulations and their underlying roles may open new avenues for cancer immunotherapy.

\section{ANTI-TUMOR ROLE OF TLS B CELLS}

Accumulating evidence indicates that TLSs play a major role in controlling tumor progression (Teillaud and Dieu-Nosjean, 2017; Figure 3). Overall, despite the heterogeneity of methods used for quantifying TLSs, studies have consistently found that high densities of intra and peritumoral TLSs are associated with prolonged overall survival and disease-free survival in more than 10 types of malignancies (Table 1), including sarcoma (Petitprez et al., 2020), melanoma (Cabrita et al., 2020), lung (Dieu-Nosjean et al., 2008; Germain et al., 2014; Tang et al., 2020; Rakaee et al., 2021), breast (Lee H.J. et al., 2016; Liu X. et al., 2017), colorectal (Coppola et al., 2011; Vayrynen et al., 2014) and pancreatic cancers (Hiraoka et al., 2015; Castino et al., 2016). The cellular composition and spatial organization of tumor-associated TLSs indicate that the development of B cell-dependent anti-tumor immunity lay the basis for the contribution of such structures to a favorable prognosis.

The presence of active GCs with $\mathrm{AID}^{+}$and $\mathrm{BCL}_{-}{ }^{+} \mathrm{B}$ cells, as well as differentiated memory B cells and plasma cells, has been detected within TLSs from diverse cancer types (Cipponi et al., 2012; Germain et al., 2014; Kroeger et al., 2016; Montfort et al., 2017; Garaud et al., 2019). Analysis of the repertoire of immunoglobulins in melanoma (Cipponi et al., 2012; Helmink et al., 2020), ovarian cancer (Kroeger et al., 2016) and invasive breast ductal carcinoma (Nzula et al., 2003) samples demonstrated B cell clonal amplification, somatic hypermutation (SHM) and CSR, revealing a local antigendriven response and antibody affinity maturation. Similarly, a comprehensive characterization of immune cells from triplenegative breast cancer patients using paired single-cell RNA and TCR/BCR sequencing revealed that tumor-infiltrating $B$ cells were mostly $\mathrm{CD} 27^{+}$memory B cells and had higher clonality, CSR and SHM than those in the blood (Hu et al., 2021). Unsupervised clustering further identified a group of $\mathrm{AICDA}^{+}$ and $\mathrm{MKI}^{+} 7^{+}$proliferative $\mathrm{B}$ cells and $\mathrm{CD}^{+} 8^{+}$plasma cells in tumor samples, underscoring the existence of functionally active GCs. Widespread B cell clonal expansions and immunoglobulin subclass switch events were also evidenced in multiple human cancers by a large-scale report, analyzing more than 30 million IgH complementarity-determining region 3 sequences assembled from $\sim 9,000$ tumor RNA-seq samples (32 cancer types) in The Cancer Genome Atlas (TCGA, Hu et al., 2019).

Activated TLS B cells may modulate T cell phenotypes within the tumor microenvironment through their ability to present tumor-derived peptides. Multiple studies have shown that tumorinfiltrating B cells with an activated/memory phenotype express markers of antigen presentation, including MHC class I and II and costimulatory molecules such as CD40, CD80, and CD86 (Nielsen et al., 2012; Shi et al., 2013; Bruno et al., 2017; Rossetti et al., 2018). Although dendritic cells are the major APCs that provide initial $\mathrm{T}$ cell activation in the lymph nodes, antigenpresenting $\mathrm{B}$ cells can contribute to additional $\mathrm{CD}^{+}{ }^{+} \mathrm{T}$ cell expansion intratumorally, as demonstrated by ex vivo co-culture assays (Bruno et al., 2017; Rossetti et al., 2018). Accordingly, in lung tumors, a high density of TLS B cells was associated with increased $\mathrm{CD} 4^{+} \mathrm{T}$ cell receptor repertoire clonality (Zhu et al., 2015) and with a reduced percentage of Tregs (Germain et al., 2021). The capacity of B cells to cross-present antigens to $\mathrm{CD}^{+} \mathrm{T}$ cells is also well established (Heit et al., 2004; Hon et al., 2005; Marino et al., 2012) and has been demonstrated in the context of the cancer testis antigen NY-ESO-1 (Gnjatic et al., 2003). Moreover, in ovarian cancer, antigen-experienced CD $20^{+}$ $\mathrm{B}$ cells colocalized with activated $\mathrm{CD} 8^{+} \mathrm{T}$ cells, and the presence of both populations correlated with increased patient survival compared with the presence of $\mathrm{CD}^{+}{ }^{+} \mathrm{T}$ cells alone (Nielsen et al., 2012). Memory B cells may also possess tumor-killing potential by producing IFN- $\gamma$, interleukin $12 p 40$ (IL-12p40), granzyme B, and TRAIL (Shi et al., 2013).

Plasma cells generated within tumor-associated TLSs may reside locally and produce significant amounts of tumor-specific antibodies, as shown for breast cancer (Coronella et al., 2002; Pavoni et al., 2007), melanoma (Erdag et al., 2012), non-small cell lung cancer (Lohr et al., 2013; Germain et al., 2014), and high-grade serous ovarian cancer (Montfort et al., 2017). Importantly, the isotype and specificity of such antibodies can drive distinct immune responses (Sharonov et al., 2020). The IgG1 antibody class is of primary importance for antitumor cytotoxic responses, as these antibodies can bind to Fc $\gamma$ receptors and trigger antibody-dependent cellular cytotoxicity and phagocytosis, complement activation, and enhance antigen presentation by dendritic cells (Gilbert et al., 2011; Boyerinas et al., 2015; Carmi et al., 2015). Accordingly, high intratumoral IgG1 has been associated with longer patient survival, while IgA may drive an opposite pattern (Welinder et al., 2016; Bolotin et al., 2017; Isaeva et al., 2019). Additionally, analysis of more than 5,000 TCGA RNA-seq samples revealed that high levels of IgG3-1 switch are associated with prolonged survival in patients with high SHM rates, whereas IgG3-1 levels are not prognostic in low SHM samples, underscoring the role of SHM in generating BCR sequences with high binding affinity to the exposed tumor antigens (Hu et al., 2019).

In prostate cancer and hepatocellular carcinoma, IgAproducing plasma cells have been shown to function as potent immunosuppressive cell populations through the expression of IL-10 and PD-L1 (Shalapour et al., 2015, 2017). On the other hand, in ovarian cancer, a recent report demonstrated that protective humoral responses are dominated by the production 
TABLE 1 | B cell and TLS presence and abundance as prognostic factors in different tumors.

\begin{tabular}{|c|c|c|c|c|c|}
\hline Author, year & Tumor type & $\mathbf{N}$ & Sample type & Method of assessment & Finding \\
\hline \multicolumn{6}{|l|}{ B lymphocytes } \\
\hline $\begin{array}{l}\text { Ladanyi et al. } \\
\text { (2011) }\end{array}$ & $\begin{array}{l}\text { Cutaneous } \\
\text { melanoma }\end{array}$ & 106 & FFPE & Immunohistochemistry & $\begin{array}{l}\text { High number of } \mathrm{CD}^{2} \mathrm{O}^{+} \mathrm{B} \text { cells (intratumoral } \\
\text { and peritumoral) associated with improved OS }\end{array}$ \\
\hline $\begin{array}{l}\text { Mahmoud et al. } \\
\text { (2012) }\end{array}$ & Breast cancer & 1,470 & FFPE & Immunohistochemistry & $\begin{array}{l}\text { Higher total CD20 }{ }^{+} \text {B cell counts associated } \\
\text { with better DFI and BCSS }\end{array}$ \\
\hline $\begin{array}{l}\text { Woo et al. } \\
(2014)\end{array}$ & Prostate carcinoma & 53 & FFPE & Immunohistochemistry & $\begin{array}{l}\text { Intratumoral CD20+ B cells associated with } \\
\text { cancer recurrence and progression }\end{array}$ \\
\hline $\begin{array}{l}\text { Germain et al. } \\
(2014)\end{array}$ & Lung cancer & $\begin{array}{l}74 \text { early stage } \\
122 \text { advanced stage }\end{array}$ & FFPE & Immunohistochemistry & $\begin{array}{l}\text { High density of follicular CD } 20^{+} \text {B cells within } \\
\text { TLSs associated with better OS }\end{array}$ \\
\hline $\begin{array}{l}\text { Castino et al. } \\
(2016)\end{array}$ & Pancreatic cancer & 104 & FFPE & Immunohistochemistry & $\begin{array}{l}\text { High density of B cells within TLSs associated } \\
\text { with improved DSS. }\end{array}$ \\
\hline $\begin{array}{l}\text { Miligy et al. } \\
\text { (2017) }\end{array}$ & Breast DCIS & 36 & FFPE & Immunohistochemistry & $\begin{array}{l}\text { High number of CD20+ } \mathrm{B} \text { cells associated with } \\
\text { shorter RFI }\end{array}$ \\
\hline $\begin{array}{l}\text { Sakimura et al. } \\
(2017)\end{array}$ & Gastric cancer & 226 & FFPE & Immunohistochemistry & $\begin{array}{l}\text { High number of } \mathrm{CD} 2 \mathrm{O}^{+} \mathrm{B} \text { cells associated with } \\
\text { longer OS }\end{array}$ \\
\hline $\begin{array}{l}\text { Arias-Pulido } \\
\text { et al. (2018) }\end{array}$ & $\begin{array}{l}\text { Inflammatory breast } \\
\text { cancer }\end{array}$ & 221 & FFPE & Immunohistochemistry & $\begin{array}{l}\mathrm{CD} 20^{+} \mathrm{PD}-\mathrm{L} 1^{+} \text {lymphocytes were an } \\
\text { independent favorable prognostic factor for } \\
\text { DFS and BCSS }\end{array}$ \\
\hline $\begin{array}{l}\text { Edin et al. } \\
\text { (2019) }\end{array}$ & Colorectal & 316 & FFPE & $\begin{array}{l}\text { Multiplexed } \\
\text { immunohistochemistry and } \\
\text { multispectral imaging }\end{array}$ & $\begin{array}{l}\text { High number of CD20 }{ }^{+} \text {B cells associated with } \\
\text { improved DSS }\end{array}$ \\
\hline $\begin{array}{l}\text { Murakami et al. } \\
\text { (2019) }\end{array}$ & Gastric cancer & 59 & FFPE & $\begin{array}{l}\text { Double staining } \\
\text { immunohistochemistry } \\
\text { (CD19 and IL-10) }\end{array}$ & $\begin{array}{l}\text { Regulatory B cells }\left(\mathrm{CD} 19^{+} \mathrm{IL} 10^{+}\right) \text {associated } \\
\text { with worse } 5 \text {-year OS rate }\end{array}$ \\
\hline $\begin{array}{l}\text { Chen et al. } \\
(2020)\end{array}$ & $\begin{array}{l}\text { NK/T-cell } \\
\text { lymphoma }\end{array}$ & 56 & FFPE & Immunohistochemistry & $\begin{array}{l}\text { High density of CD20+ } \mathrm{B} \text { cells associated with } \\
\text { improved OS }\end{array}$ \\
\hline $\begin{array}{l}\text { Petitprez et al. } \\
(2020)\end{array}$ & Sarcoma & 496 & $\begin{array}{l}\text { STS public datasets (TCGA } \\
\text { SARC, } \\
\text { GSE21050, GSE21122 and } \\
\text { GSE30929) }\end{array}$ & $\begin{array}{l}\text { Gene expression (TME } \\
\text { deconvolution) }\end{array}$ & B cell signature associated with improved OS \\
\hline
\end{tabular}

TLS

\begin{tabular}{|c|c|c|c|c|c|}
\hline $\begin{array}{l}\text { Coppola et al. } \\
\text { (2011) }\end{array}$ & Colorectal cancer & 21 & Fresh tumor & Microarray & $\begin{array}{l}\text { Higher expression of a 12-chemokine TLS } \\
\text { signature in long-term survivors }\end{array}$ \\
\hline $\begin{array}{l}\text { Vayrynen et al. } \\
\text { (2014) }\end{array}$ & Colorectal cancer & 418 (cohort 1) & FFPE & $H \& E$ & $\begin{array}{l}\text { Higher TLS density (the number of follicles/the } \\
\text { length of the invasive front) associated with } \\
\text { improved 5-year survival }\end{array}$ \\
\hline $\begin{array}{l}\text { Hiraoka et al. } \\
\text { (2015) }\end{array}$ & Pancreatic cancer & 308 & FFPE & Immunohistochemistry & $\begin{array}{l}\text { Higher relative area of intratumoral TLSs } \\
\text { associated with improved OS and DFS }\end{array}$ \\
\hline $\begin{array}{l}\text { Schweiger } \\
\text { et al. (2016) }\end{array}$ & $\begin{array}{l}\text { Colorectal cancer } \\
\text { (lung metastases) }\end{array}$ & 57 & FFPE & Immunohistochemistry & $\begin{array}{l}\text { The presence of TLSs was not associated with } \\
\text { improved RFS or OS }\end{array}$ \\
\hline $\begin{array}{l}\text { Lee H.J. et al. } \\
(2016)\end{array}$ & $\begin{array}{l}\text { Resected triple } \\
\text { negative breast } \\
\text { cancer }\end{array}$ & 769 & FFPE & $H \& E$ & $\begin{array}{l}\text { Moderate or abundant TLSs associated with } \\
\text { better DFS }\end{array}$ \\
\hline $\begin{array}{l}\text { Liu X. et al., } \\
2017\end{array}$ & $\begin{array}{l}\text { Invasive breast } \\
\text { cancer }\end{array}$ & 248 & FFPE & Immunohistochemistry & $\begin{array}{l}\text { Presence of TLS associated with improved DFS } \\
\text { in } \mathrm{HER}^{+}{ }^{+} \text {tumors }\end{array}$ \\
\hline $\begin{array}{l}\text { Silina et al. } \\
(2018)\end{array}$ & $\begin{array}{l}\text { Resected } \\
\text { squamous cell lung } \\
\text { carcinoma }\end{array}$ & 138 & FFPE & $H \& E$ & $\begin{array}{l}\text { Number of TLSs per } \mathrm{mm}^{2} \text { was the strongest } \\
\text { prognostic factor }\end{array}$ \\
\hline $\begin{array}{l}\text { Calderaro et al. } \\
\text { (2019) }\end{array}$ & $\begin{array}{l}\text { Resected } \\
\text { hepatocellular } \\
\text { carcinoma }\end{array}$ & 273 & FFPE & $H \& E$ & $\begin{array}{l}\text { Presence of intratumoral TLSs associated with } \\
\text { lower risk of early tumor relapse following } \\
\text { surgery }\end{array}$ \\
\hline $\begin{array}{l}\text { Sofopoulos } \\
\text { et al. (2019) }\end{array}$ & $\begin{array}{l}\text { Ductal breast } \\
\text { carcinoma }\end{array}$ & 112 & FFPE & $H \& E$ & $\begin{array}{l}\text { Patients with peritumoral TLSs had worse DFS } \\
\text { and OS }\end{array}$ \\
\hline $\begin{array}{l}\text { Cabrita et al. } \\
(2020)\end{array}$ & $\begin{array}{l}\text { Cutaneous } \\
\text { melanoma }\end{array}$ & 117 & FFPE & Immunohistochemistry & $\begin{array}{l}\text { Presence of TLSs and tumor associated } \mathrm{CD}^{+} \\
\text {cells associated with improved OS }\end{array}$ \\
\hline Li et al. (2020) & $\begin{array}{l}\text { Resected oral } \\
\text { cancer }\end{array}$ & 65 & FFPE & $H \& E$ & $\begin{array}{l}\text { Patients whose tumors were enriched for } \\
\text { intratumoral TLSs had better DFS and OS }\end{array}$ \\
\hline
\end{tabular}


TABLE 1 | Continued

\begin{tabular}{|c|c|c|c|c|c|}
\hline Author, year & Tumor type & $\mathbf{N}$ & Sample type & Method of assessment & Finding \\
\hline $\begin{array}{l}\text { Tang et al. } \\
(2020)\end{array}$ & Lung cancer & 133 & FFPE & Immunohistochemistry & $\begin{array}{l}\text { High TLS number per } \mathrm{mm}^{2} \text { and relative area } \\
\text { associated with improved } 10 \text {-year survival }\end{array}$ \\
\hline $\begin{array}{l}\text { Rakaee et al. } \\
\text { (2021) }\end{array}$ & Lung cancer & 553 & FFPE & Immunohistochemistry & $\begin{array}{l}\text { TLS score was an independent positive } \\
\text { prognostic factor of DFS and OS, regardless of } \\
\text { the quantification strategy used (four-scale } \\
\text { semi-quantitative; absolute count of total TLSs; } \\
\text { absolute count of total TLSs with germinal } \\
\text { center) }\end{array}$ \\
\hline
\end{tabular}

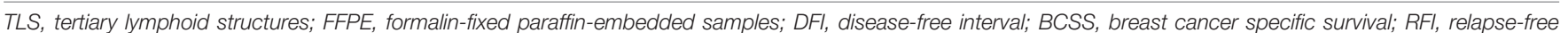

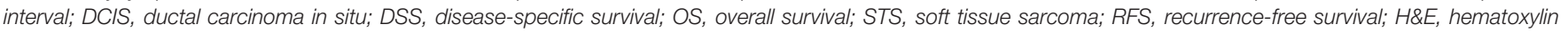
and eosin staining.

of polyclonal IgA, which binds to polymeric IgA receptors universally expressed on the tumor cells (Biswas et al., 2021). Interestingly, IgA responses were shown to impair ovarian cancer growth through complementary mechanisms: antigen-specific IgA redirected myeloid cells against cell-surface antigen-positive tumor cells, while transcytosis of non-antigen-specific IgA by tumor cells induced broad transcriptional changes, including the upregulation of IFN $-\gamma$ receptors and several DUSP phosphatases, which antagonize the RAS pathway.

Accumulating evidence shows that the functional state of tumor-infiltrating B cells is shaped by whether they are organized or not in well-structured mature TLSs (Figure 3). Careful examination of tissue slides from adenocarcinoma of the pancreas (Castino et al., 2016) and the esophagogastric junction (Knief et al., 2016) revealed that a high density of $\mathrm{CD}^{+} 0^{+} \mathrm{B}$ cells was associated with increased patient survival, but only if B cells were organized within TLSs. Similarly, the abundance of $\mathrm{CD} 20^{+} \mathrm{B}$ cells in ovarian cancer was only associated with improved prognosis in the presence of the TLS marker CXCL13. CD $20^{h i} \mathrm{CXCL} 13^{h i}$ tumors had significantly longer overall survival and progression-free survival than the $\mathrm{CD}_{20}{ }^{l o}$ or $\mathrm{CXCL}^{3}{ }^{l o}$ counterparts (Yang et al., 2021). Regulatory phenotypes may arise when B cells are scattered throughout the stroma and have substantial interaction with malignant (Zhao et al., 2018) and TGF $\beta$-producing cells, as suggested by the low $\mathrm{T}$ cell activity in immature TLSs (Cabrita et al., 2020). It is, thus, crucial to consider the spatial distribution of $\mathrm{B}$ cells to properly understand their dual role in controlling tumor progression. Importantly, experiments with pre-clinical murine models should be interpreted with caution, as fast-growing orthotopic tumors might develop a malignant cell-rich bulk with reduced stroma and devoid of TLSs (Spear et al., 2019).

It is noteworthy that TLS-rich tumors are typically more infiltrated by $\mathrm{CD}^{+} \mathrm{T}$ cells, which may express inhibitory immune checkpoints following persistent antigen exposure and/or inflammatory signals. In mature TLSs of sarcoma patients, the intimate contact between $\mathrm{B}$ and $\mathrm{T}$ cells was sufficient to induce high expression of the immune checkpoint PD1 on $\mathrm{T}$ cells (Petitprez et al., 2020). Similarly, expression levels of the inhibitory receptors TIGIT and CTLA-4 were elevated in TLS ${ }^{\text {hi }}$ non-small cell lung cancer samples compared to the TLS ${ }^{\text {lo }}$ ones (Rakaee et al., 2021). Thus, TLSs may represent a rich site of expression of clinically relevant immune checkpoints.

\section{CLINICAL APPLICATIONS AND FUTURE PERSPECTIVES}

Recent studies have demonstrated a prominent association between B cell-dependent anti-tumor immunity and responsiveness to immunotherapy in different types of cancer. Analysis of post-treatment resection specimens of non-small-cell lung carcinoma patients in the first trial of neoadjuvant anti-PD1 (nivolumab) showed that immune-mediated tumor clearance was characterized by local formation of TLSs and the presence of plasma cells (Cottrell et al., 2018). Notably, a TLS gene expression signature predicted clinical outcomes to ICB with anti-CTLA-4 and/or anti-PD-1 in multiple cohorts of melanoma samples (Cabrita et al., 2020). At baseline, melanoma-infiltrating $\mathrm{B}$ cells from responders were shown to have increased BCR clonality and diversity, as well as a higher proportion of $\mathrm{CD} 27^{+}$ memory B cells (Helmink et al., 2020). A similar predictive role for B cells organized in TLSs was observed for ICB responses in patients with renal cell carcinoma (Helmink et al., 2020) and soft tissue sarcoma (Petitprez et al., 2020). Interestingly, higher expression of the TLS marker CXCL13 was independently associated with prolonged survival and objective response in muscle-invasive bladder cancer patients treated with ICB, while no significant results were observed for non-ICB-treated patients (Groeneveld et al., 2021).

Although mounting evidence highlights the central role of $\mathrm{B}$ lymphocytes and TLS in priming effective anti-tumor immune responses (Sautes-Fridman et al., 2019), they have largely been overlooked in clinical trials that have mostly focused on reversing $\mathrm{T}$ cell exhaustion. Except for drugs developed to treat B cell lymphomas and leukemias, clinical strategies that directly modulate B lymphocytes or harness the formation of TLSs have not yet been developed for solid tumors.

Barbera-Guillem et al. (2000) used rituximab to deplete $\mathrm{B}$ cells in a mouse model of liver metastasis of colorectal carcinoma (CRC) and demonstrated a reduction in the number of metastases following treatment. In the same study, fourteen metastatic CRC patients received rituximab, and among the 8 patients who completed treatment, half had tumor regression 
and 1 achieved stable disease as evaluated by positron emission tomography (Barbera-Guillem et al., 2000).

LIGHT (TNFSF14) is a cytokine important to the development and maintenance of SLOs and TLSs. In a preclinical murine model of pancreatic cancer, the administration of LIGHT linked to a vascular targeting peptide (LIGHT-VTP) promoted the formation of TLSs, stimulated intratumoral $\mathrm{T}$ cell infiltration, enhanced response to anti-PD1 and anti-CTLA4 therapies and strongly synergized with anti-tumor vaccination (Johansson-Percival et al., 2017).

In a phase I/II study (J0810) involving potentially resectable pancreatic cancer, 59 patients were randomized, with a 1:1:1 ratio, to receive GVAX, a GM-CSF-secreting irradiated pancreatic tumor vaccine, administered intradermally alone ( $\operatorname{arm} \mathrm{A}$ ) or in combination with low dose intravenous (arm B) or oral cyclophosphamide (arm C) before and after surgery. Fifty-four patients underwent surgery, five of them did not have pancreatic adenocarcinoma, 1 had an ampullary cancer and 11 had cancer recurrence immediately following surgery, all these patients were excluded from further analysis. Among the remaining 39 patients, 33 (85\%) developed intratumoral TLS, whereas none of 54 unvaccinated patients from a previous study had lymphoid aggregates in their tumors. Besides, vaccinated patients had improved antigen specific (anti-mesothelin) $\mathrm{T}$ cell response and enhanced $\mathrm{T}$ effector/ $\mathrm{T}$ regulatory ratio. The authors did not include a control group treated with cyclophosphamide only, and despite they suggested that TLS formation was associated with longer survival; this result was underpowered and biased due to patient selection (Lutz et al., 2014). Recently, Zheng et al. (2021) updated the results of this trial after the inclusion of 38 additional patients (87 in total). Combining low dose cyclophosphamide with GVAX promoted worse disease-free survival (arm $\mathrm{A} \times \mathrm{B}$ $\times$ C: $18.92 \times 8.54 \times 5.56$ months $)$ and overall survival $(34.2$ $\times 15.4 \times 16.5)$ compared to GVAX alone. Increased density of intratumoral TLS was associated with longer overall survival (Zheng et al., 2021).

In another study, metastatic pancreatic adenocarcinoma (PDAC) patients were treated in a random fashion (2:1 ratio) with two doses of GVAX followed by 4 doses of live-attenuated Listeria monocytogenes expressing mesothelin (CRS-207) (arm A) or 6 doses of GVAX plus cyclophosphamide ( $\operatorname{arm} B)$. The combination of GVAX and CRS-207 improved median overall survival (primary endpoint) from 3.9 months in arm B to 6.1 months in arm A (HR 0.59; $p=0.02)$. Mesothelin-specific $\mathrm{T}$ cell number was higher in arm $\mathrm{A}$ as well. However, no objective responses were observed, and progression-free survival was similar in both arms, which makes it challenging to rule out an imbalance due to the effect of subsequent treatments in overall survival (Le et al., 2015).

On the other hand, Tsujikawa et al. (2020) randomized 93 metastatic PDAC patients to receive the same treatment mentioned above (GVAX+ low dose cyclophosphamide+ CRS207) with or without nivolumab (an anti-PD1 monoclonal antibody). They did not observe any difference in overall survival. The authors also analyzed 22 paired tumor samples before and after treatment and found an increase lymphoid cell density, an increased frequency of PD1-EOMES-CD ${ }^{+}$T cells and a decrease in $\mathrm{CD}^{+} 8^{+}$myeloid cells within the tumor microenvironment after cycle 3 in patients treated with GVAX and nivolumab (Tsujikawa et al., 2020).

Similarly, Wu A. A. et al. (2020) randomized 82 metastatic PDAC patients who obtained at least stable disease following 812 cycles of FOLFIRINOX (5-fluorouracil, leucovorin, irinotecan and oxaliplatin) to continue FOLFIRINOX or receive 4 doses of ipilimumab (an anti-CTLA4 monoclonal antibody) plus GVAX every 3 weeks. The study was stopped due to futility after an interim analysis; OS was shorter in the GVAX arm $(9.38 \times$ 14.7 months). Nevertheless, the authors observed an increase in effector and memory $\mathrm{T}$ cells in peripheral blood following treatment with GVAX+ ipilimumab. Similarly, they observed an increase in total $\mathrm{CD}^{+}$and $\mathrm{CD}^{+} \mathrm{T}$ cells, late effector memory $\mathrm{CD}^{+} \mathrm{T}$ cells and $\mathrm{M} 1$ macrophages and a decrease in $\mathrm{CD}^{+}{ }^{+} \mathrm{FOXP}^{+}{ }^{+}$Tregs, early effector, exhausted $\mathrm{CD} 8^{+} \mathrm{T}$ cells and M2 macrophages in the tumor microenvironment comparing tumor samples obtained before and after treatment. However, it is difficult to tease out which intervention (GVAX alone, ipilimumab or the combination) promoted the aforementioned modifications.

On the other hand, corticosteroids, diet, rituximab and chemotherapy can impair the formation of TLS and reduce the development of GCs, potentially blunting anti-tumor immune response (Liu L. et al., 2017; Silina et al., 2018; Ryan et al., 2020).

Overall, these data indicate that strategies modulating TLS development in tumor milieu may hold promise in cancer treatment and extend the use of TLS and B cells beyond prognostic and therapeutic biomarkers to therapeutic targets. Studies in the basic research field aiming to further elucidate the mechanisms governing TLS evolution in cancer may pave the way for the development of new therapeutic approaches in this sense.

\section{CONCLUDING REMARKS}

There is a growing appreciation that prominent anti-tumor immune responses are elicited when immune cells are spatially organized in privileged sites, namely TLSs, that facilitate cell-tocell interaction and optimal antigen presentation. The detailed characterization of such complex intratumoral cellular networks is gaining momentum due to their clinical relevance, since TLSs can be used as a biomarker to classify cancer patients that are likely to benefit from immunotherapy approaches. More importantly, due to their capacity of mounting coordinated antitumor $\mathrm{T}$ and $\mathrm{B}$ cell responses, TLSs can be used to identify clinically relevant cancer-related immune checkpoints, and further research may reveal strategies capable of modulating TLS formation in the tumor microenvironment. Previously neglected, B cells are now considered key cellular components that initiate and sustain anti-tumor responses, as they appear to be indispensable T lymphocyte allies in the fight against cancer cells.

\section{AUTHOR CONTRIBUTIONS}

GK, GV, WF, and AC designed the figures. All authors wrote and approved the manuscript before submission. 


\section{FUNDING}

This work was supported by funds from the São Paulo Research Foundation (FAPESP) to GK (fellowship 2019/251292) and TM (grant 2018/14034-8), by the Coordination for the Improvement of Higher Education Personnel

\section{REFERENCES}

Adler, L. N., Jiang, W., Bhamidipati, K., Millican, M., Macaubas, C., Hung, S. C., et al. (2017). The Other Function: Class II-Restricted Antigen Presentation by B Cells. Front. Immunol. 8:319. doi: 10.3389/fimmu.2017.00319

Ammirante, M., Luo, J. L., Grivennikov, S., Nedospasov, S., and Karin, M. (2010). Bcell-derived lymphotoxin promotes castration-resistant prostate cancer. Nature 464, 302-305. doi: 10.1038/nature08782

Arias-Pulido, H., Cimino-Mathews, A., Chaher, N., Qualls, C., Joste, N., Colpaert, C., et al. (2018). The combined presence of CD20 + B cells and PD-L1 + tumor-infiltrating lymphocytes in inflammatory breast cancer is prognostic of improved patient outcome. Breast Cancer Res. Treat. 171, 273-282. doi: 10.1007/s10549-018-4834-7

Bai, R., Lv, Z., Xu, D., and Cui, J. (2020). Predictive biomarkers for cancer immunotherapy with immune checkpoint inhibitors. Biomark Res. 8:34.

Barbera-Guillem, E., Nelson, M. B., Barr, B., Nyhus, J. K., May, K. F. Jr., Feng, L., et al. (2000). B lymphocyte pathology in human colorectal cancer. Experimental and clinical therapeutic effects of partial B cell depletion. Cancer Immunol. Immunother. 48, 541-549. doi: 10.1007/pl00006672

Baumgarth, N. (2017). A Hard(y) Look at B-1 Cell Development and Function. J. Immunol. 199, 3387-3394. doi: 10.4049/jimmunol.1700943

Beck, T. C., Gomes, A. C., Cyster, J. G., and Pereira, J. P. (2014). CXCR4 and a cell-extrinsic mechanism control immature B lymphocyte egress from bone marrow. J. Exp. Med. 211, 2567-2581. doi: 10.1084/jem.20140457

Bertocci, B., De Smet, A., Weill, J. C., and Reynaud, C. A. (2006) Nonoverlapping functions of DNA polymerases mu, lambda, and terminal deoxynucleotidyltransferase during immunoglobulin $\mathrm{V}(\mathrm{D}) \mathrm{J}$ recombination in vivo. Immunity 25, 31-41. doi: 10.1016/j.immuni.2006.04.013

Bibby, J. A., Purvis, H. A., Hayday, T., Chandra, A., Okkenhaug, K., Rosenzweig, S., et al. (2020). Cholesterol metabolism drives regulatory B cell IL-10 through provision of geranylgeranyl pyrophosphate. Nat. Commun. 11:3412.

Biswas, S., Mandal, G., Payne, K. K., Anadon, C. M., Gatenbee, C. D., Chaurio, R. A., et al. (2021). IgA transcytosis and antigen recognition govern ovarian cancer immunity. Nature 591, 464-470. doi: 10.1038/s41586-020-03144-0

Bolotin, D. A., Poslavsky, S., Davydov, A. N., Frenkel, F. E., Fanchi, L., Zolotareva, O. I., et al. (2017). Antigen receptor repertoire profiling from RNA-seq data. Nat. Biotechnol. 35, 908-911. doi: 10.1038/nbt.3979

Boyerinas, B., Jochems, C., Fantini, M., Heery, C. R., Gulley, J. L., Tsang, K. Y., et al. (2015). Antibody-Dependent Cellular Cytotoxicity Activity of a Novel AntiPD-L1 Antibody Avelumab (MSB0010718C) on Human Tumor Cells. Cancer Immunol. Res. 3, 1148-1157. doi: 10.1158/2326-6066.cir-15-0059

Bruno, T. C., Ebner, P. J., Moore, B. L., Squalls, O. G., Waugh, K. A., Eruslanov, E. B., et al. (2017). Antigen-Presenting Intratumoral B Cells Affect CD4(+) TIL Phenotypes in Non-Small Cell Lung Cancer Patients. Cancer Immunol. Res. 5, 898-907. doi: 10.1158/2326-6066.cir-17-0075

Buckley, C. D., Barone, F., Nayar, S., Benezech, C., and Caamano, J. (2015). Stromal cells in chronic inflammation and tertiary lymphoid organ formation. Annu. Rev. Immunol. 33, 715-745. doi: 10.1146/annurev-immunol-032713- 120252

Cabrita, R., Lauss, M., Sanna, A., Donia, M., Skaarup Larsen, M., Mitra, S., et al. (2020). Tertiary lymphoid structures improve immunotherapy and survival in melanoma. Nature 577, 561-565. doi: 10.1038/s41586-019-1914-8

Calderaro, J., Petitprez, F., Becht, E., Laurent, A., Hirsch, T. Z., Rousseau, B., et al. (2019). Intra-tumoral tertiary lymphoid structures are associated with a low risk of early recurrence of hepatocellular carcinoma. J. Hepatol. 70, 58-65. doi: 10.1016/j.jhep.2018.09.003

Carmi, Y., Spitzer, M. H., Linde, I. L., Burt, B. M., Prestwood, T. R., Perlman, N., et al. (2015). Allogeneic IgG combined with dendritic cell stimuli induce antitumour T-cell immunity. Nature 521, 99-104. doi: 10.1038/nature1 4424
(CAPES) fellowship to AC, by grants from the National Institute of Science and Technology in Oncogenomics and Therapeutic Innovation (INCITO) funded by FAPESP (grant 2014/50943-1), and the National Council for Scientific and Technological Development (CNPq, grant 465682/2014-6).

Caro-Maldonado, A., Wang, R., Nichols, A. G., Kuraoka, M., Milasta, S., Sun, L. D., et al. (2014). Metabolic reprogramming is required for antibody production that is suppressed in anergic but exaggerated in chronically BAFF-exposed B cells. J. Immunol. 192, 3626-3636. doi: 10.4049/jimmunol.1302062

Castino, G. F., Cortese, N., Capretti, G., Serio, S., Di Caro, G., Mineri, R., et al. (2016). Spatial distribution of B cells predicts prognosis in human pancreatic adenocarcinoma. Oncoimmunology 5:e1085147. doi: 10.1080/2162402x.2015. 1085147

Chaye, M. A. M., Tontini, C., Ozir-Fazalalikhan, A., Voskamp, A. L., and Smits, H. H. (2021). Use of Toll-Like Receptor (TLR) Ligation to Characterize Human Regulatory B-Cells Subsets. Methods Mol. Biol. 2270, 235-261. doi: 10.1007/ 978-1-0716-1237-8_13

Chen, M. M., Zeng, G. P., Li, J., Fu, J. H., Long, Y. Y., Pan, J. Y., et al. (2020). High infiltration of CD20(+) B lymphocytes in extranodal natural killer/T-cell lymphoma is associated with better prognosis. Br. J. Haematol. 191, e116-e120.

Chen, X., and Jensen, P. E. (2008). The role of B lymphocytes as antigen-presenting cells. Arch. Immunol. Ther. Exp. 56, 77-83.

Cherrier, M., Sawa, S., and Eberl, G. (2012). Notch, Id2, and RORgammat sequentially orchestrate the fetal development of lymphoid tissue inducer cells. J. Exp. Med. 209, 729-740. doi: 10.1084/jem.20111594

Cinamon, G., Matloubian, M., Lesneski, M. J., Xu, Y., Low, C., Lu, T., et al. (2004). Sphingosine 1-phosphate receptor 1 promotes B cell localization in the splenic marginal zone. Nat. Immunol. 5, 713-720. doi: 10.1038/ni1083

Cipponi, A., Mercier, M., Seremet, T., Baurain, J. F., Theate, I., Van Den Oord, J., et al. (2012). Neogenesis of lymphoid structures and antibody responses occur in human melanoma metastases. Cancer Res. 72, 3997-4007. doi: 10.1158/ 0008-5472.can-12- 1377

Coppola, D., Nebozhyn, M., Khalil, F., Dai, H., Yeatman, T., Loboda, A., et al. (2011). Unique ectopic lymph node-like structures present in human primary colorectal carcinoma are identified by immune gene array profiling. Am. J. Pathol. 179, 37-45. doi: 10.1016/j.ajpath.2011.03.007

Coronella, J. A., Spier, C., Welch, M., Trevor, K. T., Stopeck, A. T., Villar, H., et al. (2002). Antigen-driven oligoclonal expansion of tumor-infiltrating B cells in infiltrating ductal carcinoma of the breast. J. Immunol. 169, 1829-1836. doi: 10.4049/jimmunol.169.4.1829

Cottrell, T. R., Thompson, E. D., Forde, P. M., Stein, J. E., Duffield, A. S., Anagnostou, V., et al. (2018). Pathologic features of response to neoadjuvant anti-PD-1 in resected non-small-cell lung carcinoma: a proposal for quantitative immune-related pathologic response criteria (irPRC). Ann. Oncol. 29, 1853-1860. doi: 10.1093/annonc/mdy218

Cyster, J. G., and Allen, C. D. C. (2019). B Cell Responses: Cell Interaction Dynamics and Decisions. Cell 177, 524-540. doi: 10.1016/j.cell.2019.03.016

Dambuza, I. M., He, C., Choi, J. K., Yu, C. R., Wang, R., Mattapallil, M. J., et al. (2017). IL-12p35 induces expansion of IL-10 and IL-35-expressing regulatory $B$ cells and ameliorates autoimmune disease. Nat. Commun. 8:719.

de Wit, J., Souwer, Y., Jorritsma, T., Klaasse Bos, H., Ten Brinke, A., Neefjes, J., et al. (2010). Antigen-specific B cells reactivate an effective cytotoxic T cell response against phagocytosed Salmonella through cross-presentation. PLoS One 5:e13016. doi: 10.1371/journal.pone.0013016

Deola, S., Panelli, M. C., Maric, D., Selleri, S., Dmitrieva, N. I., Voss, C. Y., et al. (2008). Helper B cells promote cytotoxic T cell survival and proliferation independently of antigen presentation through CD27/CD70 interactions. J. Immunol. 180, 1362-1372. doi: 10.4049/jimmunol.180.3.1362

Deteix, C., Attuil-Audenis, V., Duthey, A., Patey, N., Mcgregor, B., Dubois, V., et al (2010). Intragraft Th17 infiltrate promotes lymphoid neogenesis and hastens clinical chronic rejection. J. Immunol. 184, 5344-5351. doi: 10.4049/jimmunol. 0902999

Dieu-Nosjean, M. C., Antoine, M., Danel, C., Heudes, D., Wislez, M., Poulot, V., et al. (2008). Long-term survival for patients with non-small-cell lung cancer 
with intratumoral lymphoid structures. J. Clin. Oncol. 26, 4410-4417. doi: $10.1200 /$ jco.2007.15.0284

Dobosz, P., and Dzieciatkowski, T. (2019). The Intriguing History of Cancer Immunotherapy. Front. Immunol. 10:2965. doi: 10.3389/fimmu.2019.02965

Domeier, P. P., Chodisetti, S. B., Soni, C., Schell, S. L., Elias, M. J., Wong, E. B., et al. (2016). IFN-gamma receptor and STAT1 signaling in B cells are central to spontaneous germinal center formation and autoimmunity. J. Exp. Med. 213, 715-732. doi: $10.1084 /$ jem.20151722

Domeier, P. P., Schell, S. L., and Rahman, Z. S. (2017). Spontaneous germinal centers and autoimmunity. Autoimmunity 50, 4-18. doi: 10.1080/08916934. 2017.1280671

Dong, H. P., Elstrand, M. B., Holth, A., Silins, I., Berner, A., Trope, C. G., et al. (2006). NK- and B-cell infiltration correlates with worse outcome in metastatic ovarian carcinoma. Am. J. Clin. Pathol. 125, 451-458. doi: 10.1309/ 15b66dqmfyym78cj

Edin, S., Kaprio, T., Hagstrom, J., Larsson, P., Mustonen, H., Bockelman, C., et al. (2019). The Prognostic Importance of CD20(+) B lymphocytes in Colorectal Cancer and the Relation to Other Immune Cell subsets. Sci. Rep. 9:19997.

Erdag, G., Schaefer, J. T., Smolkin, M. E., Deacon, D. H., Shea, S. M., Dengel, L. T., et al. (2012). Immunotype and immunohistologic characteristics of tumorinfiltrating immune cells are associated with clinical outcome in metastatic melanoma. Cancer Res. 72, 1070-1080. doi: 10.1158/0008-5472.can-11-3218

Escors, D., Gato-Canas, M., Zuazo, M., Arasanz, H., Garcia-Granda, M. J., Vera, R., et al. (2018). The intracellular signalosome of PD-L1 in cancer cells. Signal. Transduct. Target Ther. 3:26.

Farkona, S., Diamandis, E. P., and Blasutig, I. M. (2016). Cancer immunotherapy: the beginning of the end of cancer? BMC Med. 14:73. doi: 10.1186/s12916-0160623-5

Fillatreau, S., Sweenie, C. H., Mcgeachy, M. J., Gray, D., and Anderton, S. M. (2002). $\mathrm{B}$ cells regulate autoimmunity by provision of IL-10. Nat. Immunol. 3, 944-950. doi: $10.1038 /$ ni833

Fremd, C., Schuetz, F., Sohn, C., Beckhove, P., and Domschke, C. (2013). $\mathrm{B}$ cell-regulated immune responses in tumor models and cancer patients. Oncoimmunology 2:e25443. doi: 10.4161/onci.25443

Fuxa, M., Skok, J., Souabni, A., Salvagiotto, G., Roldan, E., and Busslinger, M. (2004). Pax5 induces V-to-DJ rearrangements and locus contraction of the immunoglobulin heavy-chain gene. Genes Dev. 18, 411-422. doi: 10.1101/gad. 291504

Ganti, S. N., Albershardt, T. C., Iritani, B. M., and Ruddell, A. (2015). Regulatory B cells preferentially accumulate in tumor-draining lymph nodes and promote tumor growth. Sci. Rep. 5:12255.

Garaud, S., Buisseret, L., Solinas, C., Gu-Trantien, C., De Wind, A., Van Den Eynden, G., et al. (2019). Tumor infiltrating B-cells signal functional humoral immune responses in breast cancer. JCI Insight 5:e129641.

Garner, H., and de Visser, K. E. (2020). Immune crosstalk in cancer progression and metastatic spread: a complex conversation. Nat. Rev. Immunol. 20, 483-497. doi: $10.1038 / \mathrm{s} 41577-019-0271-\mathrm{z}$

Gatto, D., and Brink, R. (2010). The germinal center reaction. J. Allerg. Clin. Immunol. 126, 898-907.

Germain, C., Devi-Marulkar, P., Knockaert, S., Biton, J., Kaplon, H., Letaief, L., et al. (2021). Tertiary Lymphoid Structure-B Cells Narrow Regulatory T Cells Impact in Lung Cancer Patients. Front. Immunol. 12:626776. doi: 10.3389/fimmu.2021. 626776

Germain, C., Gnjatic, S., Tamzalit, F., Knockaert, S., Remark, R., Goc, J., et al. (2014). Presence of B cells in tertiary lymphoid structures is associated with a protective immunity in patients with lung cancer. Am. J. Respir. Crit. Care Med. 189, 832-844. doi: 10.1164/rccm.2013091611 oc

Gibney, G. T., Weiner, L. M., and Atkins, M. B. (2016). Predictive biomarkers for checkpoint inhibitor-based immunotherapy. Lancet Oncol. 17, e542-e551.

Gilbert, A. E., Karagiannis, P., Dodev, T., Koers, A., Lacy, K., Josephs, D. H., et al. (2011). Monitoring the systemic human memory B cell compartment of melanoma patients for anti-tumor IgG antibodies. PLoS One 6:e19330. doi: 10.1371/journal.pone.0019330

Gnjatic, S., Atanackovic, D., Matsuo, M., Jager, E., Lee, S. Y., Valmori, D., et al. (2003). Cross-presentation of HLA class I epitopes from exogenous NY-ESO1 polypeptides by nonprofessional APCs. J. Immunol. 170, 1191-1196. doi: 10.4049/jimmunol.170.3.1191
Gotot, J., Gottschalk, C., Leopold, S., Knolle, P. A., Yagita, H., Kurts, C., et al. (2012). Regulatory T cells use programmed death 1 ligands to directly suppress autoreactive B cells in vivo. Proc. Natl. Acad. Sci. U. S. A. 109, 10468-10473. doi: 10.1073/pnas.1201131109

Groeneveld, C. S., Fontugne, J., Cabel, L., Bernard-Pierrot, I., Radvanyi, F., Allory, Y., et al. (2021). Tertiary lymphoid structures marker CXCL13 is associated with better survival for patients with advanced-stage bladder cancer treated with immunotherapy. Eur. J. Cancer 148, 181-189. doi: 10.1016/j.ejca.2021.01.036

Haas, K. M. (2011). Programmed cell death 1 suppresses B-1b cell expansion and long-lived IgG production in response to T cell-independent type 2 antigens. J. Immunol. 187, 5183-5195. doi: 10.4049/jimmunol.1101990

Han, S., Feng, S., Ren, M., Ma, E., Wang, X., Xu, L., et al. (2014). Glioma cell-derived placental growth factor induces regulatory B cells. Int. J. Biochem. Cell Biol. 57, 63-68. doi: 10.1016/j.biocel.2014.10.005

Hanahan, D., and Weinberg, R. A. (2011). Hallmarks of cancer: the next generation. Cell 144, 646-674. doi: 10.1016/j.cell.2011.02.013

Heit, A., Huster, K. M., Schmitz, F., Schiemann, M., Busch, D. H., and Wagner, H. (2004). CpG-DNA aided cross-priming by cross-presenting B cells. J. Immunol. 172, 1501-1507. doi: 10.4049/jimmunol.172.3.1501

Helmink, B. A., Reddy, S. M., Gao, J., Zhang, S., Basar, R., Thakur, R., et al. (2020). $\mathrm{B}$ cells and tertiary lymphoid structures promote immunotherapy response. Nature 577, 549-555.

Hertz, D., Dibbern, J., Eggers, L., Von Borstel, L., and Schneider, B. E. (2020). Increased male susceptibility to Mycobacterium tuberculosis infection is associated with smaller B cell follicles in the lungs. Sci. Rep. 10:5142.

Hertz, D., and Schneider, B. (2019). Sex differences in tuberculosis. Semin. Immunopathol. 41, 225-237.

Hiraoka, N., Ino, Y., Yamazaki-Itoh, R., Kanai, Y., Kosuge, T., and Shimada, K. (2015). Intratumoral tertiary lymphoid organ is a favourable prognosticator in patients with pancreatic cancer. Br. J. Cancer 112, 1782-1790. doi: 10.1038/bjc. 2015.145

Hon, H., Oran, A., Brocker, T., and Jacob, J. (2005). B lymphocytes participate in cross-presentation of antigen following gene gun vaccination. J. Immunol. 174, 5233-5242. doi: 10.4049/jimmunol.174.9.5233

Hong, S., Zhang, Z., Liu, H., Tian, M., Zhu, X., Zhang, Z., et al. (2018). B Cells Are the Dominant Antigen-Presenting Cells that Activate Naive CD4(+) T Cells upon Immunization with a Virus-Derived Nanoparticle Antigen. Immunity 49:e694.

Hu, Q., Hong, Y., Qi, P., Lu, G., Mai, X., Xu, S., et al. (2021). Atlas of breast cancer infiltrated B-lymphocytes revealed by paired single-cell RNA-sequencing and antigen receptor profiling. Nat. Commun. 12:2186.

Hu, X., Zhang, J., Wang, J., Fu, J., Li, T., Zheng, X., et al. (2019). Landscape of B cell immunity and related immune evasion in human cancers. Nat. Genet. 51, 560-567. doi: 10.1038/s41588-018-0339-x

Isaeva, O. I., Sharonov, G. V., Serebrovskaya, E. O., Turchaninova, M. A., Zaretsky, A. R., Shugay, M., et al. (2019). Intratumoral immunoglobulin isotypes predict survival in lung adenocarcinoma subtypes. J. Immunother. Cancer 7:279.

Iwata, Y., Matsushita, T., Horikawa, M., Dilillo, D. J., Yanaba, K., Venturi, G. M., et al. (2011). Characterization of a rare IL-10-competent B-cell subset in humans that parallels mouse regulatory B10 cells. Blood 117, 530-541. doi: 10.1182/blood-2010-07-294249

Johansson-Percival, A., He, B., Li, Z. J., Kjellen, A., Russell, K., Li, J., et al. (2017). De novo induction of intratumoral lymphoid structures and vessel normalization enhances immunotherapy in resistant tumors. Nat. Immunol. 18, 1207-1217. doi: 10.1038/ni.3836

Jones, P. A., Ohtani, H., Chakravarthy, A., and De Carvalho, D. D. (2019). Epigenetic therapy in immune-oncology. Nat. Rev. Cancer 19, 151-161. doi: 10.1038/s41568-019-0109-9

Jung, D., and Alt, F. W. (2004). Unraveling V(D)J recombination; insights into gene regulation. Cell 116, 299-311. doi: 10.1016/s0092-8674(04)00039-x

Jung, D., Giallourakis, C., Mostoslavsky, R., and Alt, F. W. (2006). Mechanism and control of $\mathrm{V}(\mathrm{D}) \mathrm{J}$ recombination at the immunoglobulin heavy chain locus. Аnпu. Rev. Immunol. 24, 541-570. doi: 10.1146/annurev.immunol.23.021704. 115830

Karim, M. R., and Wang, Y. F. (2019). Phenotypic identification of $\mathrm{CD} 19(+) \mathrm{CD} 5(+) \mathrm{CD} 1 \mathrm{~d}(+)$ regulatory $\mathrm{B}$ cells that produce interleukin 10 and transforming growth factor betal in human peripheral blood. Arch. Med. Sci. 15, 1176-1183. doi: 10.5114/aoms.2018.77772 
Kessel, A., Haj, T., Peri, R., Snir, A., Melamed, D., Sabo, E., et al. (2012). Human CD19(+)CD25(high) B regulatory cells suppress proliferation of CD4(+) T cells and enhance Foxp3 and CTLA-4 expression in T-regulatory cells. Autoimmun. Rev. 11, 670-677. doi: 10.1016/j.autrev.2011.11.018

Khan, A. R., Hams, E., Floudas, A., Sparwasser, T., Weaver, C. T., and Fallon, P. G. (2015). PD-L1hi B cells are critical regulators of humoral immunity. Nat. Commun. 6:5997.

Knief, J., Reddemann, K., Petrova, E., Herhahn, T., Wellner, U., and Thorns, C. (2016). High Density of Tumor-infiltrating B-Lymphocytes and Plasma Cells Signifies Prolonged Overall Survival in Adenocarcinoma of the Esophagogastric Junction. Anticancer Res. 36, 5339-5345. doi: 10.21873/anticanres.11107

Kroeger, D. R., Milne, K., and Nelson, B. H. (2016). Tumor-Infiltrating Plasma Cells Are Associated with Tertiary Lymphoid Structures. Cytol. T Cell Resp. 22, 3005-3015. doi: 10.1158/1078-0432.ccr-15-2762

Ladanyi, A., Kiss, J., Mohos, A., Somlai, B., Liszkay, G., Gilde, K., et al. (2011). Prognostic impact of B-cell density in cutaneous melanoma. Cancer Immunol. Immunother. 60, 1729-1738.

Le, D. T., Wang-Gillam, A., Picozzi, V., Greten, T. F., Crocenzi, T., Springett, G., et al. (2015). Safety and survival with GVAX pancreas prime and Listeria Monocytogenes-expressing mesothelin (CRS-207) boost vaccines for metastatic pancreatic cancer. J. Clin. Oncol. 33, 1325-1333. doi: 10.1200/jco.2014.57.4244

Lee-Chang, C., Bodogai, M., Martin-Montalvo, A., Wejksza, K., Sanghvi, M., Moaddel, R., et al. (2013). Inhibition of breast cancer metastasis by resveratrolmediated inactivation of tumor-evoked regulatory B cells. J. Immunol. 191, 4141-4151. doi: 10.4049/jimmunol.1300606

Lee, H. J., Park, I. A., Song, I. H., Shin, S. J., Kim, J. Y., Yu, J. H., et al. (2016). Tertiary lymphoid structures: prognostic significance and relationship with tumour-infiltrating lymphocytes in triple-negative breast cancer. J. Clin. Pathol. 69, 422-430. doi: 10.1136/jclinpath-2015-203089

Lee, K. E., Spata, M., Bayne, L. J., Buza, E. L., Durham, A. C., Allman, D., et al. (2016). Hifla Deletion Reveals Pro-Neoplastic Function of B Cells in Pancreatic Neoplasia. Cancer Discov. 6, 256-269. doi: 10.1158/2159-8290.cd-15-0822

Li, K., Guo, Q., Zhang, X., Dong, X., Liu, W., Zhang, A., et al. (2020). Oral cancerassociated tertiary lymphoid structures: gene expression profile and prognostic value. Clin. Exp. Immunol. 199, 172-181. doi: 10.1111/cei.13389

Lindner, S., Dahlke, K., Sontheimer, K., Hagn, M., Kaltenmeier, C., Barth, T. F., et al. (2013). Interleukin 21-induced granzyme B-expressing B cells infiltrate tumors and regulate T cells. Cancer Res. 73, 2468-2479. doi: 10.1158/0008-5472.can12-3450

Liu, L., Nishihara, R., Qian, Z. R., Tabung, F. K., Nevo, D., Zhang, X., et al. (2017). Association Between Inflammatory Diet Pattern and Risk of Colorectal Carcinoma Subtypes Classified by Immune Responses to Tumor. Gastroenterology 153:e1514.

Liu, X., Tsang, J. Y. S., Hlaing, T., Hu, J., Ni, Y. B., Chan, S. K., et al. (2017). Distinct Tertiary Lymphoid Structure Associations and Their Prognostic Relevance in HER2 Positive and Negative Breast Cancers. Oncologist 22, 1316-1324. doi: 10.1634/theoncologist.2017-0029

Lohr, M., Edlund, K., Botling, J., Hammad, S., Hellwig, B., Othman, A., et al. (2013). The prognostic relevance of tumour-infiltrating plasma cells and immunoglobulin kappa $\mathrm{C}$ indicates an important role of the humoral immune response in non-small cell lung cancer. Cancer Lett. 333, 222-228. doi: 10.1016/ j.canlet.2013.01.036

Lorenz, R. G., Chaplin, D. D., Mcdonald, K. G., Mcdonough, J. S., and Newberry, R. D. (2003). Isolated lymphoid follicle formation is inducible and dependent upon lymphotoxin-sufficient B lymphocytes, lymphotoxin beta receptor, and TNF receptor I function. J. Immunol. 170, 5475-5482. doi: 10.4049/jimmunol. 170.11 .5475

Lundgren, S., Berntsson, J., Nodin, B., Micke, P., and Jirstrom, K. (2016). Prognostic impact of tumour-associated B cells and plasma cells in epithelial ovarian cancer. J. Ovarian Res. 9:21.

Lutz, E. R., Wu, A. A., Bigelow, E., Sharma, R., Mo, G., Soares, K., et al. (2014). Immunotherapy converts nonimmunogenic pancreatic tumors into immunogenic foci of immune regulation. Cancer Immunol. Res. 2, 616-631. doi: 10.1158/2326-6066.cir-14-0027

Mahmoud, S. M., Lee, A. H., Paish, E. C., Macmillan, R. D., Ellis, I. O., and Green, A. R. (2012). The prognostic significance of B lymphocytes in invasive carcinoma of the breast. Breast Cancer Res. Treat. 132, 545-553. doi: 10.1007/ s10549-011-1620-1
Marino, E., Tan, B., Binge, L., Mackay, C. R., and Grey, S. T. (2012). B-cell cross-presentation of autologous antigen precipitates diabetes. Diabetes 61, 2893-2905. doi: 10.2337/db12-0006

Matsumoto, M., Baba, A., Yokota, T., Nishikawa, H., Ohkawa, Y., Kayama, H., et al. (2014). Interleukin-10-producing plasmablasts exert regulatory function in autoimmune inflammation. Immunity 41, 1040-1051. doi: 10.1016/j.immuni. 2014.10.016

Matsumoto, M., and Baba, Y. (2013). [Role of STIM-dependent $\mathrm{Ca}(2+)$ influx in regulatory B cells]. Yakugaku Zasshi 133, 419-425. doi: 10.1248/yakushi.1200227-2

Matsumoto, M., Fujii, Y., Baba, A., Hikida, M., Kurosaki, T., and Baba, Y. (2011). The calcium sensors STIM1 and STIM2 control B cell regulatory function through interleukin-10 production. Immunity 34, 703-714. doi: 10.1016/j. immuni.2011.03.016

Matsushita, T. (2019). Regulatory and effector B cells: Friends or foes? J. Dermatol. Sci. 93, 2-7. doi: 10.1016/j.jdermsci.2018.11.008

Mauri, C., and Menon, M. (2017). Human regulatory B cells in health and disease: therapeutic potential. J. Clin. Invest. 127, 772-779. doi: 10.1172/jci8 5113

McDonald, K. G., Mcdonough, J. S., and Newberry, R. D. (2005). Adaptive immune responses are dispensable for isolated lymphoid follicle formation: antigen-naive, lymphotoxin-sufficient B lymphocytes drive the formation of mature isolated lymphoid follicles. J. Immunol. 174, 5720-5728. doi: 10.4049/ jimmunol.174.9.5720

Mebius, R. E., Streeter, P. R., Michie, S., Butcher, E. C., and Weissman, I. L. (1996). A developmental switch in lymphocyte homing receptor and endothelial vascular addressin expression regulates lymphocyte homing and permits CD4+ CD3- cells to colonize lymph nodes. Proc. Natl. Acad. Sci. U. S. A. 93, 1101911024. doi: 10.1073/pnas.93.20.11019

Medina, K. L., and Singh, H. (2005). Gene regulatory networks orchestrating B cell fate specification, commitment, and differentiation. Curr. Top Microbiol. Immunol. 290, 1-14. doi: 10.1007/3-540-26363-2_1

Meng, X., Grotsch, B., Luo, Y., Knaup, K. X., Wiesener, M. S., Chen, X. X., et al. (2018). Hypoxia-inducible factor-1alpha is a critical transcription factor for IL-10-producing B cells in autoimmune disease. Nat. Commun. 9:251.

Menon, M., Blair, P. A., Isenberg, D. A., and Mauri, C. (2016). A Regulatory Feedback between Plasmacytoid Dendritic Cells and Regulatory B Cells Is Aberrant in Systemic Lupus Erythematosus. Immunity 44, 683-697. doi: 10. 1016/j.immuni.2016.02.012

Meylan, M., Petitprez, F., Lacroix, L., Di Tommaso, L., Roncalli, M., Bougouin, A., et al. (2020). Early Hepatic Lesions Display Immature Tertiary Lymphoid Structures and Show Elevated Expression of Immune Inhibitory and Immunosuppressive Molecules. Clin. Cancer Res. 26, 4381-4389.

Miligy, I., Mohan, P., Gaber, A., Aleskandarany, M. A., Nolan, C. C., DiezRodriguez, M., et al. (2017). Prognostic significance of tumour infiltrating B lymphocytes in breast ductal carcinoma in situ. Histopathology 71, 258-268. doi: 10.1111/his.13217

Montfort, A., Pearce, O., Maniati, E., Vincent, B. G., Bixby, L., Bohm, S., et al. (2017). A Strong B-cell Response Is Part of the Immune Landscape in Human High-Grade Serous Ovarian Metastases. Clin. Cancer Res. 23, 250-262. doi: 10.1158/1078-0432.ccr-16-0081

Moulin, V., Andris, F., Thielemans, K., Maliszewski, C., Urbain, J., and Moser, M. (2000). B lymphocytes regulate dendritic cell (DC) function in vivo: increased interleukin 12 production by DCs from B cell-deficient mice results in Thelper cell type 1 deviation. J. Exp. Med. 192, 475-482. doi: 10.1084/jem.192.4.475

Murakami, Y., Saito, H., Shimizu, S., Kono, Y., Shishido, Y., Miyatani, K., et al. (2019). Increased regulatory B cells are involved in immune evasion in patients with gastric cancer. Sci. Rep. 9:13083.

Nayar, S., Campos, J., Smith, C. G., Iannizzotto, V., Gardner, D. H., Mourcin, F., et al. (2019). Immunofibroblasts are pivotal drivers of tertiary lymphoid structure formation and local pathology. Proc. Natl. Acad. Sci. U. S. A. 116, 13490-13497. doi: 10.1073/pnas.19053 01116

Nielsen, J. S., Sahota, R. A., Milne, K., Kost, S. E., Nesslinger, N. J., Watson, P. H., et al. (2012). CD20+ tumor-infiltrating lymphocytes have an atypical CD27- memory phenotype and together with CD8+ T cells promote favorable prognosis in ovarian cancer. Clin. Cancer Res. 18, 3281-3292. doi: 10.1158/ 1078-0432.ccr-12-0234 
Nishimura, H., Minato, N., Nakano, T., and Honjo, T. (1998). Immunological studies on PD-1 deficient mice: implication of PD-1 as a negative regulator for B cell responses. Int. Immunol. 10, 1563-1572. doi: 10.1093/intimm/10.10.1563

Nouel, A., Pochard, P., Simon, Q., Segalen, I., Le Meur, Y., Pers, J. O., et al. (2015). B-Cells induce regulatory $T$ cells through TGF-beta/IDO production in A CTLA-4 dependent manner. J. Autoimmun. 59, 53-60. doi: 10.1016/j.jaut. 2015.02.004

Nzula, S., Going, J. J., and Stott, D. I. (2003). Antigen-driven clonal proliferation, somatic hypermutation, and selection of B lymphocytes infiltrating human ductal breast carcinomas. Cancer Res. 63, 3275-3280.

Okazaki, T., Maeda, A., Nishimura, H., Kurosaki, T., and Honjo, T. (2001). PD-1 immunoreceptor inhibits B cell receptor-mediated signaling by recruiting src homology 2-domain-containing tyrosine phosphatase 2 to phosphotyrosine. Proc. Natl. Acad. Sci. U. S. A. 98, 13866-13871. doi: 10.1073/pnas.231486598

Oleinika, K., Mauri, C., and Salama, A. D. (2019). Effector and regulatory B cells in immune-mediated kidney disease. Nat. Rev. Nephrol. 15, 11-26. doi: 10.1038/ s41581-018-0074-7

Olkhanud, P. B., Damdinsuren, B., Bodogai, M., Gress, R. E., Sen, R., Wejksza, K., et al. (2011). Tumor-evoked regulatory B cells promote breast cancer metastasis by converting resting CD4(+) T cells to T-regulatory cells. Cancer Res. 71, 3505-3515. doi: 10.1158/0008-5472.can-10-4316

Pavoni, E., Monteriu, G., Santapaola, D., Petronzelli, F., Anastasi, A. M., Pelliccia, A., et al. (2007). Tumor-infiltrating B lymphocytes as an efficient source of highly specific immunoglobulins recognizing tumor cells. BMC Biotechnol. 7:70. doi: 10.1186/1472-6750-7-70

Peduto, L., Dulauroy, S., Lochner, M., Spath, G. F., Morales, M. A., Cumano, A., et al. (2009). Inflammation recapitulates the ontogeny of lymphoid stromal cells. J. Immunol. 182, 5789-5799. doi: 10.4049/jimmunol.0803974

Peters, A., Pitcher, L. A., Sullivan, J. M., Mitsdoerffer, M., Acton, S. E., Franz, B., et al. (2011). Th17 cells induce ectopic lymphoid follicles in central nervous system tissue inflammation. Immunity 35, 986-996. doi: 10.1016/j.immuni. 2011.10.015

Petitprez, F., De Reynies, A., Keung, E. Z., Chen, T. W., Sun, C. M., Calderaro, J., et al. (2020). B cells are associated with survival and immunotherapy response in sarcoma. Nature 577, 556-560.

Pieper, K., Grimbacher, B., and Eibel, H. (2013). B-cell biology and development. J. Allergy Clin. Immunol. 131, 959-971.

Pillai, S., and Cariappa, A. (2009). The follicular versus marginal zone B lymphocyte cell fate decision. Nat. Rev. Immunol. 9, 767-777. doi: 10.1038/ nri2656

Pimenta, E. M., De, S., Weiss, R., Feng, D., Hall, K., Kilic, S., et al. (2015). IRF5 is a novel regulator of CXCL13 expression in breast cancer that regulates CXCR5(+) B- and T-cell trafficking to tumor-conditioned media. Immunol. Cell Biol. 93, 486-499. doi: 10.1038/icb.2014.110

Piper, C. J. M., Rosser, E. C., Oleinika, K., Nistala, K., Krausgruber, T., Rendeiro, A. F., et al. (2019). Aryl Hydrocarbon Receptor Contributes to the Transcriptional Program of IL-10-Producing Regulatory B Cells. Cell Rep. 29, 1878-1892 e7.

Pipi, E., Nayar, S., Gardner, D. H., Colafrancesco, S., Smith, C., and Barone, F. (2018). Tertiary Lymphoid Structures: Autoimmunity Goes Local. Front. Immunol. 9:1952. doi: 10.3389/fimmu.2018.01952

Pitzalis, C., Jones, G. W., Bombardieri, M., and Jones, S. A. (2014). Ectopic lymphoid-like structures in infection, cancer and autoimmunity. Nat. Rev. Immunol. 14, 447-462. doi: 10.1038/nri3700

Posch, F., Silina, K., Leibl, S., Mundlein, A., Moch, H., Siebenhuner, A., et al. (2018). Maturation of tertiary lymphoid structures and recurrence of stage II and III colorectal cancer. Oncoimmunology 7:e1378844. doi: 10.1080/2162402x.2017. 1378844

Pylayeva-Gupta, Y., Das, S., Handler, J. S., Hajdu, C. H., Coffre, M., Koralov, S. B., et al. (2016). IL35-Producing B Cells Promote the Development of Pancreatic Neoplasia. Cancer Discov. 6, 247-255. doi: 10.1158/2159-8290.cd-150843

Qian, L., Bian, G. R., Zhou, Y., Wang, Y., Hu, J., Liu, X., et al. (2015). Clinical significance of regulatory B cells in the peripheral blood of patients with oesophageal cancer. Cent. Eur. J. Immunol. 40, 263-265. doi: 10.5114/ceji.2015. 52840

Rakaee, M., Kilvaer, T. K., Jamaly, S., Berg, T., Paulsen, E. E., Berglund, M., et al. (2021). Tertiary lymphoid structure score: a promising approach to refine the
TNM staging in resected non-small cell lung cancer. Br. J. Cancer. doi: 10.1038/ s41416-021-01307-y [Epub Online ahead of print].

Ran, Z., Yue-Bei, L., Qiu-Ming, Z., and Huan, Y. (2020). Regulatory B Cells and Its Role in Central Nervous System Inflammatory Demyelinating Diseases. Front. Immunol. 11:1884. doi: 10.3389/fimmu.2020.01884

Ren, Z., Peng, H., and Fu, Y. X. (2016). PD-1 Shapes B Cells as Evildoers in the Tumor Microenvironment. Cancer Discov. 6, 477-478. doi: 10.1158/21598290.cd-16-0307

Ricciardi, M., Zanotto, M., Malpeli, G., Bassi, G., Perbellini, O., Chilosi, M., et al. (2015). Epithelial-to-mesenchymal transition (EMT) induced by inflammatory priming elicits mesenchymal stromal cell-like immune-modulatory properties in cancer cells. Br. J. Cancer 112, 1067-1075. doi: 10.1038/bjc.2015.29

Rieger, M. A., and Schroeder, T. (2012). Hematopoiesis. Cold Spring Harb. Perspect. Biol. 140, 2463-2467.

Rivera, A., Chen, C. C., Ron, N., Dougherty, J. P., and Ron, Y. (2001). Role of B cells as antigen-presenting cells in vivo revisited: antigen-specific B cells are essential for $\mathrm{T}$ cell expansion in lymph nodes and for systemic $\mathrm{T}$ cell responses to low antigen concentrations. Int. Immunol. 13, 1583-1593. doi: 10.1093/intimm/13. 12.1583

Romanow, W. J., Langerak, A. W., Goebel, P., Wolvers-Tettero, I. L., Van Dongen, J. J., Feeney, A. J., et al. (2000). E2A and EBF act in synergy with the V(D)J recombinase to generate a diverse immunoglobulin repertoire in nonlymphoid cells. Mol. Cell 5, 343-353. doi: 10.1016/s1097-2765(00)80429-3

Rosser, E. C., Oleinika, K., Tonon, S., Doyle, R., Bosma, A., Carter, N. A., et al. (2014). Regulatory B cells are induced by gut microbiota-driven interleukin1beta and interleukin-6 production. Nat. Med. 20, 1334-1339. doi: 10.1038/ nm. 3680

Rossetti, R. A. M., Lorenzi, N. P. C., Yokochi, K., Rosa, M., Benevides, L., Margarido, P. F. R., et al. (2018). B lymphocytes can be activated to act as antigen presenting cells to promote anti-tumor responses. PLoS One 13:e0199034. doi: 10.1371/journal.pone.0199034

Roya, N., Fatemeh, T., Faramarz, M. A., Milad, S. G., Mohammad-Javad, S., Najmeh, S. V., et al. (2020). Frequency of IL-10+CD19+ B cells in patients with prostate cancer compared to patients with benign prostatic hyperplasia. Afr. Health Sci. 20, 1264-1272. doi: 10.4314/ahs.v20i3.31

Ryan, S. T., Zhang, J., Burner, D. N., Liss, M., Pittman, E., Muldong, M., et al. (2020). Neoadjuvant rituximab modulates the tumor immune environment in patients with high risk prostate cancer. J. Transl. Med. 18:214.

Sakimura, C., Tanaka, H., Okuno, T., Hiramatsu, S., Muguruma, K., Hirakawa, K., et al. (2017). B cells in tertiary lymphoid structures are associated with favorable prognosis in gastric cancer. J. Surg. Res. 215, 74-82. doi: 10.1016/j.jss.2017.03. 033

Sarvaria, A., Madrigal, J. A., and Saudemont, A. (2017). B cell regulation in cancer and anti-tumor immunity. Cell Mol. Immunol. 14, 662-674. doi: 10.1038/cmi. 2017.35

Sautes-Fridman, C., Petitprez, F., Calderaro, J., and Fridman, W. H. (2019). Tertiary lymphoid structures in the era of cancer immunotherapy. Nat. Rev. Cancer 19, 307-325. doi: 10.1038/s41568-019-0144-6

Saze, Z., Schuler, P. J., Hong, C. S., Cheng, D., Jackson, E. K., and Whiteside, T. L. (2013). Adenosine production by human B cells and B cell-mediated suppression of activated T cells. Blood 122, 9-18. doi: 10.1182/blood-2013-02482406

Schlosser, H. A., Thelen, M., Lechner, A., Wennhold, K., Garcia-Marquez, M. A., Rothschild, S. I., et al. (2019). B cells in esophago-gastric adenocarcinoma are highly differentiated, organize in tertiary lymphoid structures and produce tumor-specific antibodies. Oncoimmunology 8:e1512458. doi: 10.1080/ 2162402x.2018.1512458

Schumacher, T. N., and Schreiber, R. D. (2015). Neoantigens in cancer immunotherapy. Science 348, 69-74.

Schwartz, M., Zhang, Y., and Rosenblatt, J. D. (2016). B cell regulation of the anti-tumor response and role in carcinogenesis. J. Immunother. Cancer 4:40.

Schweiger, T., Berghoff, A. S., Glogner, C., Glueck, O., Rajky, O., Traxler, D., et al. (2016). Tumor-infiltrating lymphocyte subsets and tertiary lymphoid structures in pulmonary metastases from colorectal cancer. Clin. Exp. Metastasis 33, 727-739. doi: 10.1007/s10585-016-9813-y

Sebina, I., and Pepper, M. (2018). Humoral immune responses to infection: common mechanisms and unique strategies to combat pathogen immune evasion tactics. Curr. Opin. Immunol. 51, 46-54. doi: 10.1016/j.coi.2018.02.001 
Shalapour, S., Font-Burgada, J., Di Caro, G., Zhong, Z., Sanchez-Lopez, E., Dhar, D., et al. (2015). Immunosuppressive plasma cells impede T-cell-dependent immunogenic chemotherapy. Nature 521, 94-98. doi: 10.1038/nature14395

Shalapour, S., Lin, X. J., Bastian, I. N., Brain, J., Burt, A. D., Aksenov, A. A., et al. (2017). Inflammation-induced IgA + cells dismantle anti-liver cancer immunity. Nature 551, 340-345. doi: 10.1038/nature24302

Shao, Y., Lo, C. M., Ling, C. C., Liu, X. B., Ng, K. T., Chu, A. C., et al. (2014). Regulatory B cells accelerate hepatocellular carcinoma progression via CD40/CD154 signaling pathway. Cancer Lett. 355, 264-272. doi: 10.1016/j. canlet.2014.09.026

Sharonov, G. V., Serebrovskaya, E. O., Yuzhakova, D. V., Britanova, O. V., and Chudakov, D. M. (2020). B cells, plasma cells and antibody repertoires in the tumour microenvironment. Nat. Rev. Immunol. 20, 294-307. doi: 10.1038/ s41577-019-0257-X

Shen, M., Wang, J., Yu, W., Zhang, C., Liu, M., Wang, K., et al. (2018). A novel MDSC-induced PD-1(-)PD-L1(+) B-cell subset in breast tumor microenvironment possesses immuno-suppressive properties. Oncoimmunology 7:e1413520. doi: 10.1080/2162402x.2017.1413520

Shi, J. Y., Gao, Q., Wang, Z. C., Zhou, J., Wang, X. Y., Min, Z. H., et al. (2013). Margin-infiltrating CD20(+) B cells display an atypical memory phenotype and correlate with favorable prognosis in hepatocellular carcinoma. Clin. Cancer Res. 19, 5994-6005. doi: 10.1158/1078-0432.ccr-12-3497

Shimabukuro-Vornhagen, A., Schlosser, H. A., Gryschok, L., Malcher, J., Wennhold, K., Garcia-Marquez, M., et al. (2014). Characterization of tumorassociated B-cell subsets in patients with colorectal cancer. Oncotarget 5, 4651-4664.

Shin, D. H., Lin, H., Zheng, H., Kim, K. S., Kim, J. Y., Chun, Y. S., et al. (2014). HIF1alpha-mediated upregulation of TASK-2 K(+) channels augments $\mathrm{Ca}(2)(+)$ signaling in mouse B cells under hypoxia. J. Immunol. 193, 4924-4933. doi: 10.4049/jimmunol.1301829

Sigvardsson, M. (2018). Molecular Regulation of Differentiation in Early B-Lymphocyte Development. Int. J. Mol. Sci. 19:1928. doi: 10.3390/ ijms 19071928

Silina, K., Soltermann, A., Attar, F. M., Casanova, R., Uckeley, Z. M., Thut, H., et al. (2018). Germinal Centers Determine the Prognostic Relevance of Tertiary Lymphoid Structures and Are Impaired by Corticosteroids in Lung Squamous Cell Carcinoma. Cancer Res. 78, 1308-1320. doi: 10.1158/0008-5472.can-171987

Sofopoulos, M., Fortis, S. P., Vaxevanis, C. K., Sotiriadou, N. N., Arnogiannaki, N., Ardavanis, A., et al. (2019). The prognostic significance of peritumoral tertiary lymphoid structures in breast cancer. Cancer Immunol. Immunother. 68, 1733-1745. doi: 10.1007/s00262-019-02407-8

Somasundaram, R., Zhang, G., Fukunaga-Kalabis, M., Perego, M., Krepler, C., Xu, X., et al. (2017). Tumor-associated B-cells induce tumor heterogeneity and therapy resistance. Nat. Commun. 8:607.

Spear, S., Candido, J. B., Mcdermott, J. R., Ghirelli, C., Maniati, E., Beers, S. A., et al. (2019). Discrepancies in the Tumor Microenvironment of Spontaneous and Orthotopic Murine Models of Pancreatic Cancer Uncover a New Immunostimulatory Phenotype for B Cells. Front. Immunol. 10:542. doi: 10.3389/fimmu.2019.00542

Tang, J., Ramis-Cabrer, D., Curull, V., Wang, X., Mateu-Jimenez, M., Pijuan, L., et al. (2020). B Cells and Tertiary Lymphoid Structures Influence Survival in Lung Cancer Patients with Resectable Tumors. Cancers 12:2644. doi: 10.3390/ cancers 12092644

Tao, H., Lu, L., Xia, Y., Dai, F., Wang, Y., Bao, Y., et al. (2015). Antitumor effector B cells directly kill tumor cells via the Fas/FasL pathway and are regulated by IL-10. Eur. J. Immunol. 45, 999-1009. doi: 10.1002/eji.2014 44625

Teillaud, J. L., and Dieu-Nosjean, M. C. (2017). Tertiary lymphoid structures: an anti-tumor school for adaptive immune cells and an antibody factory to fight cancer? Front. Immunol. 8:830. doi: 10.3389/fimmu.2017.00830

Tsujikawa, T., Crocenzi, T., Durham, J. N., Sugar, E. A., Wu, A. A., Onners, B., et al. (2020). Evaluation of Cyclophosphamide/GVAX Pancreas Followed by ListeriaMesothelin (CRS-207) with or without Nivolumab in Patients with Pancreatic Cancer. Clin. Cancer Res. 26, 3578-3588. doi: 10.1158/1078-0432.ccr-193978

van de Pavert, S. A., Olivier, B. J., Goverse, G., Vondenhoff, M. F., Greuter, M., Beke, P., et al. (2009). Chemokine CXCL13 is essential for lymph node initiation and is induced by retinoic acid and neuronal stimulation. Nat. Immunol. 10, 1193-1199. doi: 10.1038/ni.1789

van de Veen, W., Stanic, B., Yaman, G., Wawrzyniak, M., Sollner, S., Akdis, D. G., et al. (2013). IgG4 production is confined to human IL-10-producing regulatory B cells that suppress antigen-specific immune responses. J. Allergy Clin. Immunol. 131, 1204-1212. doi: 10.1016/j.jaci.2013.01.014

van der Leun, A. M., Thommen, D. S., and Schumacher, T. N. (2020). CD8(+) T cell states in human cancer: insights from single-cell analysis. Nat. Rev. Cancer 20, 218-232. doi: 10.1038/s41568-019-0235-4

Vayrynen, J. P., Sajanti, S. A., Klintrup, K., Makela, J., Herzig, K. H., Karttunen, T. J., et al. (2014). Characteristics and significance of colorectal cancer associated lymphoid reaction. Int. J. Cancer 134, 2126-2135. doi: 10.1002/ijc. 28533

Veiga-Fernandes, H., Coles, M. C., Foster, K. E., Patel, A., Williams, A., Natarajan, D., et al. (2007). Tyrosine kinase receptor RET is a key regulator of Peyer's patch organogenesis. Nature 446, 547-551. doi: 10.1038/nature05597

Vettermann, C., and Schlissel, M. S. (2010). Allelic exclusion of immunoglobulin genes: models and mechanisms. Immunol. Rev. 237, 22-42. doi: 10.1111/j.1600065x.2010.00935.x

Vickovic, S., Eraslan, G., Salmen, F., Klughammer, J., Stenbeck, L., Schapiro, D., et al. (2019). High-definition spatial transcriptomics for in situ tissue profiling. Nat. Methods 16, 987-990. doi: 10.1038/s41592-019-0548-y

Vondenhoff, M. F., Greuter, M., Goverse, G., Elewaut, D., Dewint, P., Ware, C. F., et al. (2009). LTbetaR signaling induces cytokine expression and up-regulates lymphangiogenic factors in lymph node anlagen. J. Immunol. 182, 5439-5445. doi: 10.4049/jimmunol.0801165

Wang, K., Liu, J., and Li, J. (2018). IL-35-producing B cells in gastric cancer patients. Medicine 97:e0710. doi: 10.1097/md.0000000000010710

Wang, L., Fu, Y., and Chu, Y. (2020). Regulatory B Cells. Adv. Exp. Med. Biol. 1254, 87-103.

Wang, R. X., Yu, C. R., Dambuza, I. M., Mahdi, R. M., Dolinska, M. B., Sergeev, Y. V., et al. (2014). Interleukin-35 induces regulatory B cells that suppress autoimmune disease. Nat. Med. 20, 633-641. doi: 10.1038/nm.3554

Wang, W. W., Yuan, X. L., Chen, H., Xie, G. H., Ma, Y. H., Zheng, Y. X., et al. (2015). CD19+CD24hiCD38hiBregs involved in downregulate helper T cells and upregulate regulatory T cells in gastric cancer. Oncotarget 6, 33486-33499. doi: 10.18632/oncotarget.5588

Wang, Y., Schafer, C. C., Hough, K. P., Tousif, S., Duncan, S. R., Kearney, J. F., et al. (2018). Myeloid-Derived Suppressor Cells Impair B Cell Responses in Lung Cancer through IL-7 and STAT5. J. Immunol. 201, 278-295. doi: 10.4049/ jimmunol.1701069

Wei, X., Jin, Y., Tian, Y., Zhang, H., Wu, J., Lu, W., et al. (2016). Regulatory B cells contribute to the impaired antitumor immunity in ovarian cancer patients. Tumour. Biol. 37, 6581-6588. doi: 10.1007/s13277-015-4538-0

Wejksza, K., Lee-Chang, C., Bodogai, M., Bonzo, J., Gonzalez, F. J., Lehrmann, E., et al. (2013). Cancer-produced metabolites of 5-lipoxygenase induce tumorevoked regulatory B cells via peroxisome proliferator-activated receptor alpha. J. Immunol. 190, 2575-2584. doi: 10.4049/jimmunol.1201920

Welinder, C., Jirstrom, K., Lehn, S., Nodin, B., Marko-Varga, G., Blixt, O., et al. (2016). Intra-tumour IgA1 is common in cancer and is correlated with poor prognosis in bladder cancer. Heliyon 2:e00143. doi: 10.1016/j.heliyon.2016. e00143

Winter, S., Loddenkemper, C., Aebischer, A., Rabel, K., Hoffmann, K., Meyer, T. F., et al. (2010). The chemokine receptor CXCR5 is pivotal for ectopic mucosa-associated lymphoid tissue neogenesis in chronic Helicobacter pyloriinduced inflammation. J. Mol. Med. 88, 1169-1180. doi: 10.1007/s00109-0100658-6

Woo, J. R., Liss, M. A., Muldong, M. T., Palazzi, K., Strasner, A., Ammirante, M., et al. (2014). Tumor infiltrating B-cells are increased in prostate cancer tissue. J. Transl. Med. 12:30. doi: 10.1186/1479-5876-12-30

Wouters, M. C. A., and Nelson, B. H. (2018). Prognostic Significance of TumorInfiltrating B Cells and Plasma Cells in Human Cancer. Clin. Cancer Res. 24, 6125-6135. doi: 10.1158/1078-0432.ccr-18-1481

Wu, A. A., Bever, K. M., Ho, W. J., Fertig, E. J., Niu, N., Zheng, L., et al. (2020). A Phase II Study of Allogeneic GM-CSF-Transfected Pancreatic Tumor Vaccine (GVAX) with Ipilimumab as Maintenance Treatment for Metastatic Pancreatic Cancer. Clin. Cancer Res. 26, 5129-5139. doi: 10.1158/1078-0432.ccr-201025 
Wu, H., Su, Z., and Barnie, P. A. (2020a). The role of B regulatory (B10) cells in inflammatory disorders and their potential as therapeutic targets. Int. Immunopharmacol. 78:106111. doi: 10.1016/j.intimp.2019.106111

Wu, H., Xia, L., Jia, D., Zou, H., Jin, G., Qian, W., et al. (2020b). PD-L1(+) regulatory $\mathrm{B}$ cells act as a $\mathrm{T}$ cell suppressor in a $\mathrm{PD}-\mathrm{L} 1$-dependent manner in melanoma patients with bone metastasis. Mol. Immunol. 119, 83-91. doi: 10.1016/j.molimm.2020.01.008

Xiao, X., Lao, X. M., Chen, M. M., Liu, R. X., Wei, Y., Ouyang, F. Z., et al. (2016). PD-1hi Identifies a Novel Regulatory B-cell Population in Human Hepatoma That Promotes Disease Progression. Cancer Discov. 6, 546-559. doi: 10.1158/ 2159-8290.cd-15-1408

Yang, C., Lee, H., Pal, S., Jove, V., Deng, J., Zhang, W., et al. (2013). B cells promote tumor progression via STAT3 regulated-angiogenesis. PLoS One 8:e64159. doi: 10.1371/journal.pone.0064159

Yang, M., Lu, J., Zhang, G., Wang, Y., He, M., Xu, Q., et al. (2021). CXCL13 shapes immunoactive tumor microenvironment and enhances the efficacy of PD-1 checkpoint blockade in high-grade serous ovarian cancer. J. Immunother. Cancer 9:e001136 doi: 10.1136/jitc-2020-001136

Ye, L., Zhang, Q., Cheng, Y., Chen, X., Wang, G., Shi, M., et al. (2018). Tumorderived exosomal HMGB1 fosters hepatocellular carcinoma immune evasion by promoting TIM-1(+) regulatory B cell expansion. J. Immunother. Cancer 6:145.

Yoshizaki, A., Miyagaki, T., Dilillo, D. J., Matsushita, T., Horikawa, M., Kountikov, E. I., et al. (2012). Regulatory B cells control T-cell autoimmunity through IL-21-dependent cognate interactions. Nature 491, 264-268. doi: 10.1038/ nature 11501

Zhang, C., Xin, H., Zhang, W., Yazaki, P. J., Zhang, Z., Le, K., et al. (2016). CD5 Binds to Interleukin-6 and Induces a Feed-Forward Loop with the Transcription Factor STAT3 in B Cells to Promote Cancer. Immunity 44, 913-923. doi: 10.1016/j.immuni.2016.04.003

Zhang, K. (2003). Accessibility control and machinery of immunoglobulin class switch recombination. J. Leukoc Biol. 73, 323-332. doi: 10.1189/jlb.0702339

Zhang, Y., and Zhang, Z. (2020). The history and advances in cancer immunotherapy: understanding the characteristics of tumor-infiltrating immune cells and their therapeutic implications. Cell Mol. Immunol. 17, 807821. doi: 10.1038/s41423-020-0488-6
Zhao, D. M., Thornton, A. M., Dipaolo, R. J., and Shevach, E. M. (2006). Activated CD4+CD25+ T cells selectively kill B lymphocytes. Blood 107, 3925-3932. doi: 10.1182/blood-2005-11-4502

Zhao, Y., Shen, M., Feng, Y., He, R., Xu, X., Xie, Y., et al. (2018). Regulatory B cells induced by pancreatic cancer cell-derived interleukin-18 promote immune tolerance via the PD-1/PD-L1 pathway. Oncotarget 9, 14803-14814. doi: 10. 18632/oncotarget.22976

Zheng, L., Ding, D., Edil, B. H., Judkins, C., Durham, J. N., Thomas, D. L. II, et al. (2021). Vaccine-Induced Intratumoral Lymphoid Aggregates Correlate with Survival Following Treatment with a Neoadjuvant and Adjuvant Vaccine in Patients with Resectable Pancreatic Adenocarcinoma. Clin. Cancer Res. 27, 1278-1286. doi: 10.1158/1078-0432.ccr-20-2974

Zhou, J., Min, Z., Zhang, D., Wang, W., Marincola, F., and Wang, X. (2014). Enhanced frequency and potential mechanism of B regulatory cells in patients with lung cancer. J. Transl. Med. 12:304.

Zhou, X., Su, Y. X., Lao, X. M., Liang, Y. J., and Liao, G. Q. (2016). CD19(+)IL-10(+) regulatory $\mathrm{B}$ cells affect survival of tongue squamous cell carcinoma patients and induce resting $\mathrm{CD} 4(+) \mathrm{T}$ cells to $\mathrm{CD} 4(+)$ Foxp3(+) regulatory T cells. Oral. Oncol. 53, 27-35. doi: 10.1016/j.oraloncology.2015.11.003

Zhu, W., Germain, C., Liu, Z., Sebastian, Y., Devi, P., Knockaert, S., et al. (2015). A high density of tertiary lymphoid structure B cells in lung tumors is associated with increased CD4(+) T cell receptor repertoire clonality. Oncoimmunology 4:e1051922. doi: 10.1080/2162402x.2015.1051922

Conflict of Interest: The authors declare that the research was conducted in the absence of any commercial or financial relationships that could be construed as a potential conflict of interest.

Copyright (c) 2021 Kinker, Vitiello, Ferreira, Chaves, Cordeiro de Lima and Medina. This is an open-access article distributed under the terms of the Creative Commons Attribution License (CC BY). The use, distribution or reproduction in other forums is permitted, provided the original author(s) and the copyright owner(s) are credited and that the original publication in this journal is cited, in accordance with accepted academic practice. No use, distribution or reproduction is permitted which does not comply with these terms. 